IZA DP No. 5458

Job Creation by Firms in Denmark

Rikke Ibsen

Niels Westergaard-Nielsen

January 2011 


\title{
Job Creation by Firms in Denmark
}

\author{
Rikke lbsen \\ Itracks and CCP, Aarhus School of Business \\ Niels Westergaard-Nielsen \\ $C C P$, Aarhus School of Business, \\ Aarhus University and IZA
}
Discussion Paper No. 5458
January 2011

IZA

P.O. Box 7240

53072 Bonn

Germany

Phone: +49-228-3894-0

Fax: +49-228-3894-180

E-mail: iza@iza.org

\begin{abstract}
Any opinions expressed here are those of the author(s) and not those of IZA. Research published in this series may include views on policy, but the institute itself takes no institutional policy positions.

The Institute for the Study of Labor (IZA) in Bonn is a local and virtual international research center and a place of communication between science, politics and business. IZA is an independent nonprofit organization supported by Deutsche Post Foundation. The center is associated with the University of Bonn and offers a stimulating research environment through its international network, workshops and conferences, data service, project support, research visits and doctoral program. IZA engages in (i) original and internationally competitive research in all fields of labor economics, (ii) development of policy concepts, and (iii) dissemination of research results and concepts to the interested public.
\end{abstract}

IZA Discussion Papers often represent preliminary work and are circulated to encourage discussion. Citation of such a paper should account for its provisional character. A revised version may be available directly from the author. 
IZA Discussion Paper No. 5458

January 2011

\section{ABSTRACT}

\section{Job Creation by Firms in Denmark}

In this paper we will look at job creation and destruction in firms. We will answer the question if it is the large companies that create jobs, while the smaller companies are contributing much less. Or is it the young companies that create jobs? And who destroys the most jobs? In the crisis Denmark lost 186,000 jobs in the private sector. The question is where and how could these jobs be recreated. Are these issues specific to industries or are they universal? The data used is register data on workplaces and firms for the period 1980-2007. The base unit of data is the workplace. The company (firm) is the legal entity. A company can have many sites, and one of the ways companies can grow is by expanding with multiple sites. This can happen by mergers and acquisitions but can also happen by creating "daughter workplaces". It is therefore essential to look at workplaces and firms at the same time. A complication here is that firms switch ID over time because of change of ownership, mergers and divisions. Data must be corrected so that these administrative issues will not affect the survival of firms. The data are used in a way where we can cover firm birth and firm death, spin-offs and mergers. The analysis will make it possible to differentiate between net and gross creation of jobs because we can follow each single individual in and out of jobs. We have for Denmark found that size on its own does not have a big impact, but young firms are much more likely to contribute to a positive growth. For the U.S. it has been found that the growth in jobs comes from small businesses. A closer analysis though shows that the main factor here is the firm age. Thus, it is found that young firms net create the most jobs, but they are also responsible for the most job destructions.

JEL Classification: E24, L25, L26

Keywords: job creation, job destruction, firm age, firm size, education, employer-employee data

Corresponding author:

Niels Westergård-Nielsen

Department of Economics

Aarhus School of Business and Social Sciences

Frichshuset

Hermodsvej 22

DK 8230 Aabyhøj

Denmark

E-mail: nwn@asb.dk

\footnotetext{
* Erhvervs- og Byggestyrelsen, Ministry of Economic Affairs has funded this study. Michael Ibsen has supported the data work. John Haltiwanger is thanked for comments at the Sandbjerg conference Fall 2010 and Dorte Høegh Koch is thanked for her comments on the latest version of the paper.
} 


\section{Introduction}

Jobs are all the time being destroyed and created in an economy. In growth periods more jobs are created than destroyed so there will be a net growth in the number of jobs and unemployment will subsequently go down. In other periods creations are lower than destructions and net job growth becomes negative and unemployment goes up. This is part of a normal process of reallocating jobs to more efficient use of labour. This is a common finding in all the studies of job dynamics, see the seminal book by Davis, Haltiwanger and Schuh, 1996.

During the 2008-2009 period many jobs were destroyed in the private sector. Under normal circumstances other jobs would have been recreated, but due to the crisis, many jobs were not recreated. In 2009 the net result was that Denmark had lost 186.000 jobs in the private sector, Statistics Denmark, 2010. The short run question is of course where will they be recreated if anywhere at all?

The longer run question is to identify the mechanisms that lead to job creation and job destruction. Finding key factors may help our understanding on how to influence the process and help policy makers on how to create efficient policies.

In the last 10 to 15 years there has been a growing literature on job creation and destruction and the dynamics of this process. The number of studies has intensified with a growing production of data sets suitable for studying the dynamics of employment. More and more countries are now producing data that can be used for studying the simultaneous job creation and destruction, see Lazear and Shaw, 2008.

However, most of the data sets cannot be used directly because of problems of identifying the right units and consistency of identities over time. The common pattern is that data are collected for tax purposes or for statistical purposes. For direct tax purposes it suffices to have and to maintain a registration of firm birth and death. But if you also want to register employment and the earnings of the employee for tax purposes or unemployment benefit contributions as in the USA you may be more interested in doing so at each particular workplace. As a result many countries have a mixture of these two types of registration. The Nordic countries are no exception to this. Here data are collected at both firm and workplace level, but with an emphasis on workplace levelin the employment statistics and on the firm level in the economic statistics. In all cases it is a major task for researchers to reshape data 
into something that is coherent and consistent over time. This is also a problem in the USA where Haltiwanger and others have been doing a large effort to disentangle the problems, so data can be used in a coherent and analytical way. The most recent work in that direction is Haltiwanger, Jarmin and Miranda, 2010. Hethey and Schmieder, 2010 report a similar work for Germany.

Most studies of job growth have been investigating workplaces ${ }^{2}$, and have found that job growth happens when workplaces are created or in the first years of their lifetime. Similarly, it is usually found that older workplaces net destroy jobs, (Eriksson, Li, Ibsen and Westergaard-Nielsen, 2006). The reason for the this is that when you start a workplace you usually design it for a certain number of employees. And older workplaces are similarly destroying jobs because the closure rate is higher for older workplaces and every time they make investments, it will be with new labour saving technology.

However, workplaces are not the unit that makes investment decisions, firms make these decisions. Though there are many cases ( 80 pct.) where firm and workplace is the same, there are also many cases where they are not. Therefore, it is necessary to construct firm level data in order to investigate where jobs are created and destroyed and which firms are responsible for the bulk of destruction and creation.

In this paper we will first construct data that allows us to define a firm ID in order to be able to follow firms over time from the otherwise much better defined workplace ID. With a proper identity of a firm over time we can start looking at their job creation and find determinants for job growth.

\section{Firm statistics}

Defining identity of firms over time is not as straight forward that one should think mainly because of the nature of the data. All who have worked with data on individuals are used to follow persons over time. This is straightforward because persons as a general rule do not change identity over time, or at least we don't observe that. Thus, we can follow a person from birth to death because the ID does not change. With firms it is different.

A firm gets an ID number when it is created first time. That ID number follows the firm but not as consistent as for persons. If something happens to the firm the number will change. The most common thing that could happen is that the firm changes ownership or type of

\footnotetext{
2 See Dunne, Roberts and Samuelson (1989).
} 
ownership. This will most often give the firm a new ID number. So, if you correct nothing this would look like a net destruction of a firm (and of all the jobs) and the creation of a new together with all its jobs. Of course this administrative change has not created new jobs at all and should not be counted as gross growth. That means that we have to have a mechanism that can identify these changes.

Another possibility is that this firm spins off a new firm. If the old firm has 100 employees and spins off 10 of its employees to the new firm, this creates a new firm, but no one will say that this creates more jobs net. Similarly, if one firm buys another firm and if it simply takes over all the employees. If you use the data directly without corrections you will observe the acquisition as a job destruction in the acquired firm and a similar job creation in the acquiring firm. However, the two movements should net out, since no new jobs are created. But one firm has stopped and it has destroyed all the jobs, yet another has grown by acquiring the firm and its employees.

If it was not an acquisition but a merger, matters become more complicated. An example will demonstrate the difficulties. Firm A and B merge. A has 100 employees in time $\mathrm{t}-1$ and $\mathrm{B}$ has 200. Afterwards in time t, the newly merged firm has 300 employees. You can't say that either A or B has ceased to exist, because both are still in business. Neither can you say that a new firm $A+B$ has been created. One solution is to let both $A$ and $B$ have no growth but terminate them in $\mathrm{t}$. $\mathrm{A}+\mathrm{B}$ grows according to the average size between $\mathrm{t}-1$ and $\mathrm{t}$, which means that all growth between $\mathrm{t}-1$ and $\mathrm{t}$ happens in $\mathrm{A}+\mathrm{B}$. In this case the size would be 300 .

The physical sub unit of a firm is a workplace. Firms can own one or several workplaces. Growth can happen as a growth at the workplace level but can also happen as a spin off from existing workplaces. Often this type of growth is happening in for example discount food chains but also manufacturing companies are doing it. The buildings and the present structure within each store or plant prevent them from varying the number of employees at the workplace level. Instead they will have to grow by multiplication i.e. a new workplace.

Net growth is measured in two ways. First, as the growth from time t- 1 to $t$ divided with the base employment in $\mathrm{t}-1$. This is called the base year method. Second, as the net growth in firms from time $t-1$ to $t$ divided with the average of the size in $t$ and $t-1$. This is done in order to avoid problems with the so called regression to the mean fallacy. The fallacy arises because firms that had a positive transitory chock in $\mathrm{t}-1$ are less likely to have growth in the 
subsequent period because they have already become large. And similarly, firms that have had a negative transitory chock in t-1 are more likely to be small in t- 1 and to have a larger growth in the subsequent period. Thus, the association between size and growth will tend to be negative if the base year ( $t-1)$ is used. Similarly, using end year $(\mathrm{t})$ would produce a positive bias.

Haltiwanger, Jarmin and Miranda, 2010, use what they call the "current year base" defined as the mean size between the two years. This measure serves as a compromise between either negative or positive bias.

Growth is calculated as percentages and is of course a problem because the first job created produces an enormous growth, i.e. the percentage growth from no employee to 1 employee is enormous. The convention created in the works of Haltiwanger (see Davies, Haltiwanger and Schuh, 1996) is that this growth is counted as $200 \%{ }^{3}$. The growth from 1 to 2 persons is just $100 \%$. Similarly, if a firm goes from 2 to 1 employees, the destruction rate will only be $50 \%$ and from 1 to no employees the convention is $-200 \%$. Thus, there is a build-in bias in creation and destruction when there are many creations and destructions between 0 and 1 employee. It is obvious that the bias gradually disappears with increasing size. Using the current year concept moderates this build-in bias. The bias will of course be more important for small firms than for bigger. If there are more small firms in Denmark than the U.S. the bias (higher percentages) will be more pronounced for Denmark. See the appendix for the formulas used in this paper.

Below the firm ID there is a workplace registration as well. Many statistical agencies including Statistics Denmark register the workplace (establishment), which is the physical plant where people work. This registration is linked to a physical address. Firms on the other hand can have many establishments under them in the form of production sites or shops for example. Where the firm is the legal and economic entity that runs the firm and files the annual report and pays the tax, the establishment (workplace) is a subsidiary, which only is registered because it is the address where the employees actually work. So firms can have many workplaces but a workplace can only have one firm.

The following supplementary rules are applied to the data:

\footnotetext{
3 Under the current year convention this is calculated as 1 divided by the average firm size between $t=1$ and $t=2$, which is $1 / 0.5=2$ or $200 \%$.
} 
Firm age: first time a firm enters or age of oldest establishment in firm. None of the workplaces have any connection to previous workplaces. Similarly, a firm death is when the last workplace of the firm stops.

An establishment is in the original dataset when it employs at least one half-man year. This means, that firms can exist with no employees in November in one or more years, and have November employees in other years. Since we remove students with a yearly income lower than €6700 from the data, we will have more establishments with no employees than the original dataset. However, if anestablishment in the firm does not have any employees in the period, 1981-2007, the firm is deleted from the dataset. This is important, because a lot of firms never get further than this threshold.

We use ATP data ${ }^{4}$ on the individual contributions to the pension scheme. In 1980 there is a record for the accumulated sum of contributions from the present employer. From that we can calculate the individual starting year with that particular employer. Since ATP data goes back to 1964 we can in this way find the starting date of many firms. However, not all firms starting before 1980 can be found in the ATP-data so the result is an overrepresentation of firms born in 1980 and a bias in the number of young firms the closer we are to 1980.

After an age is given to the firm on entrance, the firm ages whether there are changes in ownership for the whole firm or not.

Spin-offs have the age of the mother firm, while the receiving firm maintains its age.

Figure 1: Firm size and number of establishments (workplaces).

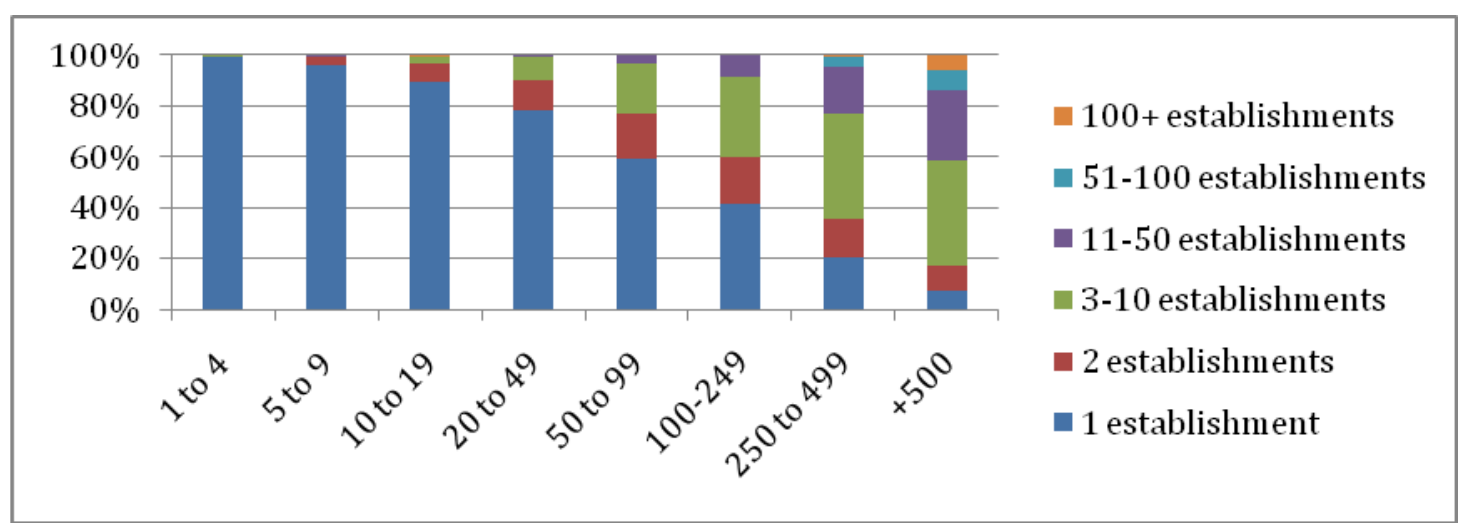

${ }^{4}$ ATP is a mandatory pension savings scheme where the contribution is directly related to the number of hours worked and has a link to the employer registration number 
Figure 1 shows the relationship between size and number of establishments after we have corrected the data as described above: The bigger the firm the more establishments belong to the firm. But the table also shows that $80 \%$ of what is considered to be a big firm in Denmark, i.e. firms with more than 250 employees has more than one establishment. That suggests clearly that acquiring/starting more workplacesis one of the ways a firm grows bigger. This is also why it would be wrong to investigate job growth based on workplaces.

Some of the firms are themselves part of an enterprise group. The enterprise group is unfortunately not yet identified in the Danish data. In the USA it is identified via a survey and used by Haltiwanger, Jarmin and Miranda. The effect of this difference is that the smaller Danish firms look even smaller than they should compared to the US and that less of the job growth will happen in bigger firms.

\section{Net job creation and gross job creation.}

The proposed measure of net growth is of course very different from gross job creation. Where the net growth in the private sector in Denmark over a long period has been negative, the gross job creation has been positive.

The difference between using the workplace and the firm as the unit can be illustrated by our earlier results in Eriksson, Li, Ibsen and Westergård-Nielsen, 2006. Here we analyzed the job flows in Denmark 1990-2001 with a pure workplace concept without taking into account which firm made the decisions on creating jobs at which workplaces. That analysis showed that the main job creation seemingly happens in workplaces that are 2 years old or less. Similarly, it is found that the bulk of all net job creation happens in small and new workplaces. However, this does not take into account that some of these new workplaces may actually belong to a bigger firm or are spin-offs of larger existing firms.

This study will investigate which types of firms are responsible for the net job creation. This will get closer to where the economic decisions are taken. It is obvious that policy target changes, if the main or substantial part of all net job creation happens because of spin offs from old firms rather than from start-ups.

In the next section of the paper we will present various descriptive statistics that gives an impression of the data with a few comparisons to US data. Second, we will by estimation try to 
disentangle the decisive factors for the job growth. Third, we will investigate the impact of human capital at the firm level, thus answering the question if firms with more human capital (HC) are creating or destroying more jobs than others.

\section{Data}

First, we have analyzed the employment firm size distribution and used the base size concept. The most common firm size groups, which are not of equal size, are the smallest firms, where more than $20 \%$ are employed in firms with 1 to 10 employees. The similar figure for the US is 11\% (Haltiwanger et al, 2010). The main difference to the US is, that US has many more large firms, so that +1000 firms employ about $44 \%$ of all where they only employ $11 \%$ in Denmark. Besides this level effect the patterns look alike. The higher fraction in large firms in the US is of course partly due to the missing enterprise group data for Denmark ${ }^{5}$.

Figure 2: Employment Firm Size Distribution:Base Firm Size, Average 1980-2007

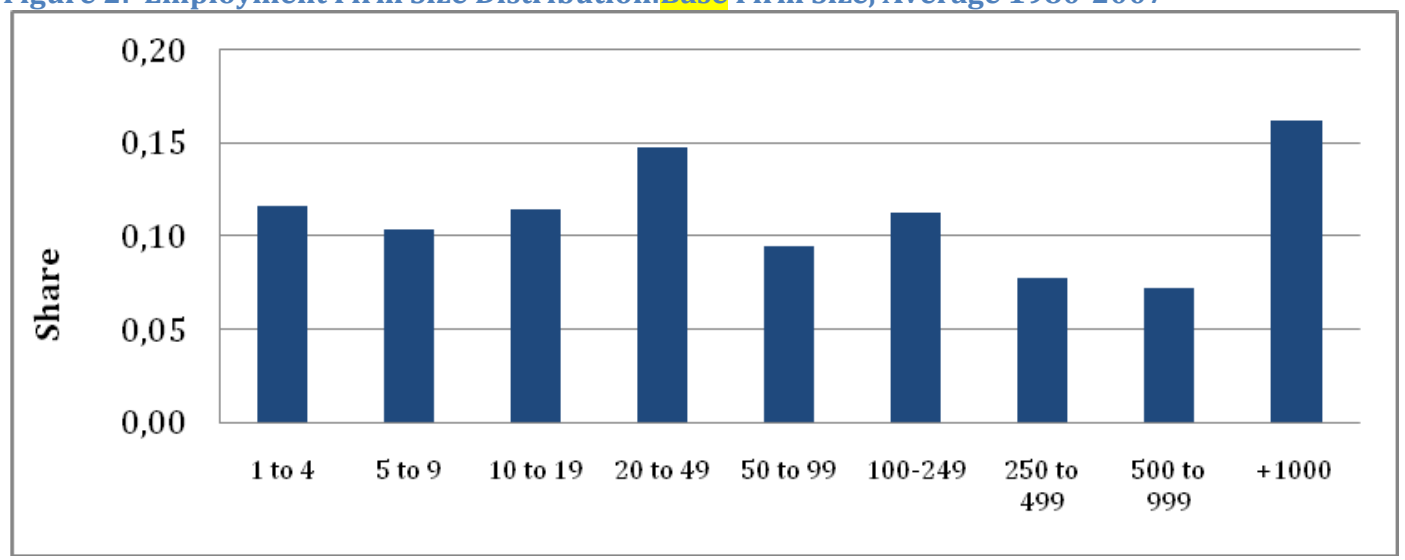

Second, we have in Figure 3 looked at the age distribution for the period 1981-2007 and for 1995-2007 as well.This shows that about 80\% of all jobs are in firms older than 15 years and that only few are employed in younger firms with an increasing column height with age. The similar distribution for the US shows that about 65\% are employed in older firms (15 years + ) and accordingly, relatively more are employed in newly created firms. The latter could be because spin-off firms in the US are classified as new where they in Denmark are given the age of the mother firm. The columns show that the firms have become older after 1995, but this may be due to the censoring of ages before 1980, so it is most likely that on average Danish firms are substantially older than US firms despite they are bigger.

\footnotetext{
5 In Danish “koncern”
} 
Figure 3: Employment Firm Share: By Firm Age Class, Average 1981-2007 and Average 1995-2007

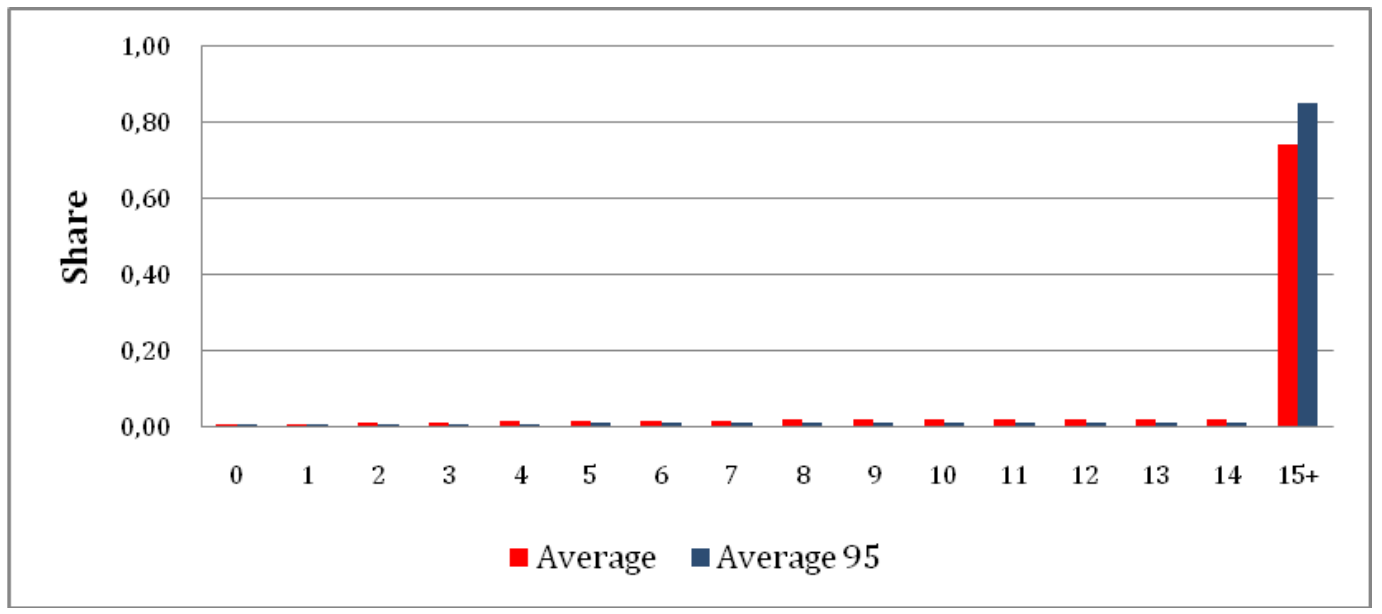

Now, combining firm age and size gives a three-dimensional graph. Figure 4 shows that small young firms are responsible for a relatively larger employment than larger young firms. Nevertheless, Figure 4 indicates that older firms are responsible for most of the entire employment and among the older firms the larger firms have a high share.

Figure 4: Average Annual Employment by Firm Age and Size, 1981-2007

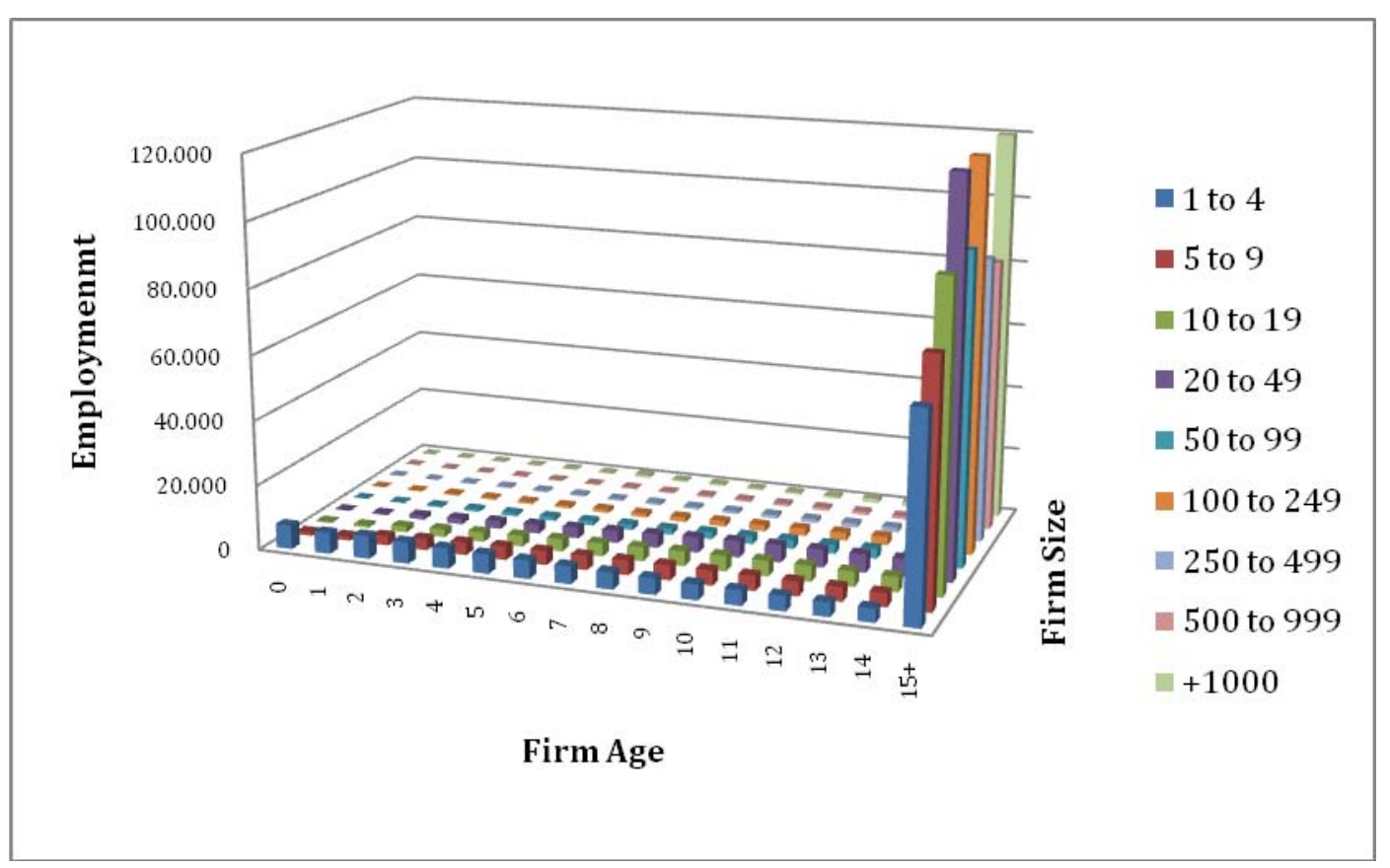


If we make a cut through the starting firms (age=0) then we get the pattern in Figure 5. This histogram shows clearly that most of all start-ups happen as small firms in Denmark. This is similar in the U.S. according to Haltiwanger et al.

Figure 5: Share of Startups within Firm Size Class Current Firm Size, Average 1981-2007

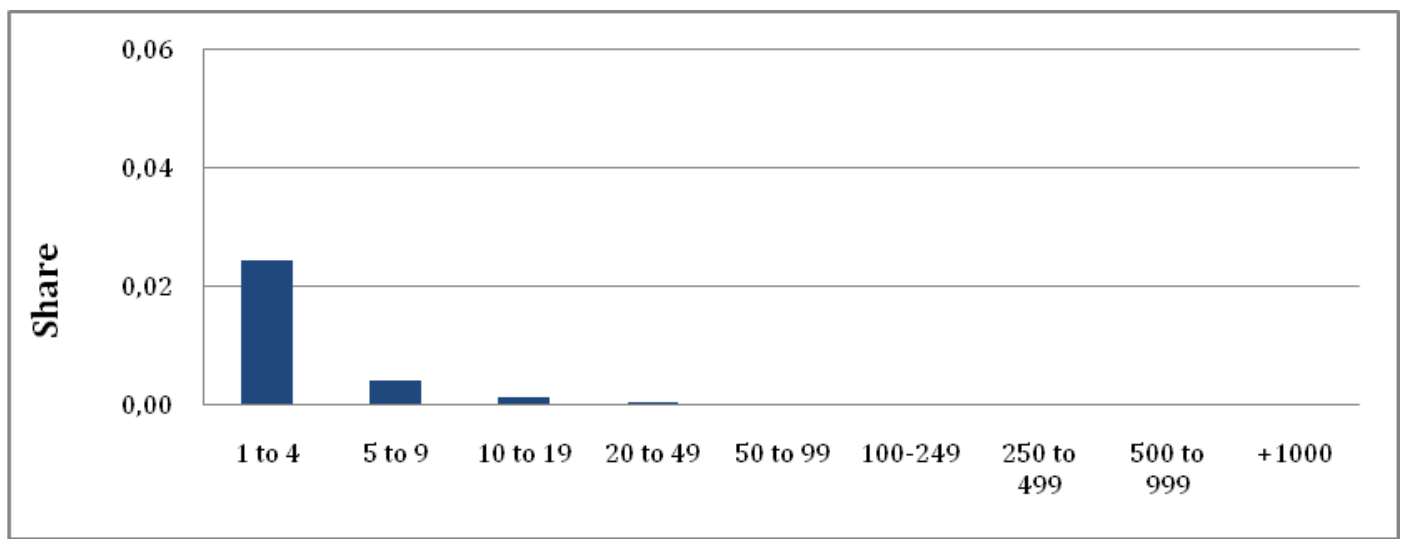

Not unexpectedly, there seems to be a close link between start-ups and size. If we look at the average age for firms according to size we can see an age gradient in the sense that the average age goes up with firm size. However, it is at the same time remarkable that the average age of even the small firms is so high. That indicates that a number of small firms never get bigger. This could have something to do with the type and industry of these small firms.

Figure 6: Average Firm Age by Firm Size, Continuing Firm in 2007, Employment Weighted

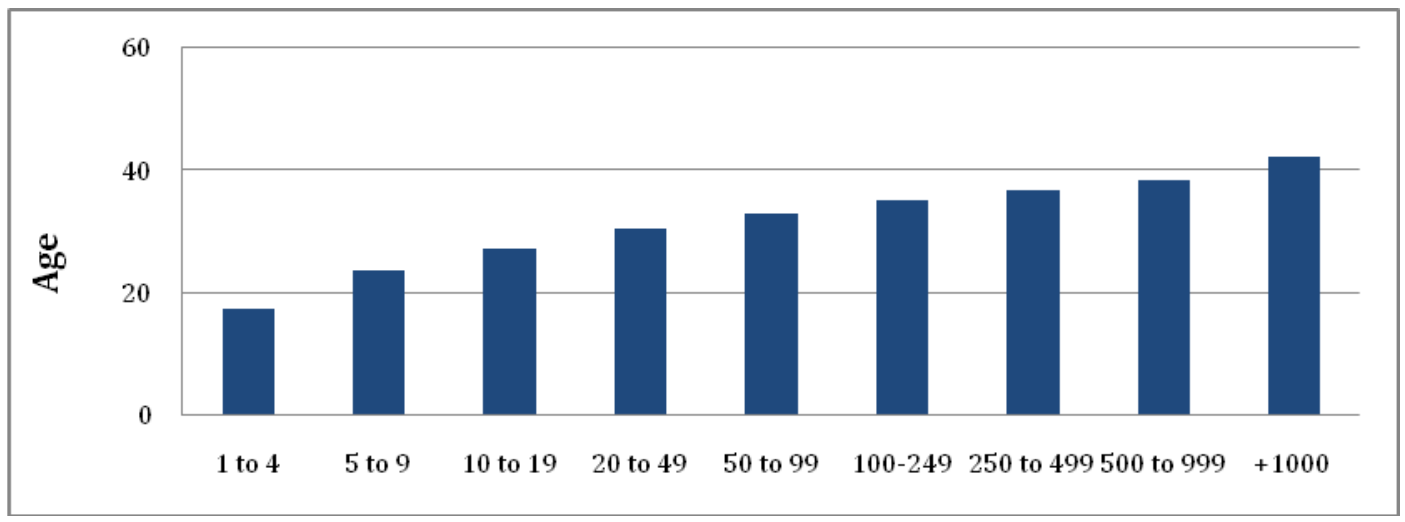




\section{Composition of gross job development}

With the concepts developed we are able to describe under which circumstances jobs are created and destroyed through the business cycle ${ }^{6}$. Thus, Figure 7 describes the job creation of firms expanding (upsizing), job destruction of down sizing firms, job creation of new firms, and job destruction of closed firms. It is evident from the figure that upsizing and downsizing are highly dependent on business cycles. At the same time, it is found that jobs created due to new firms or closure of firms is rather constant over time and seems to be almost independent of business cycles.

Figure 7. The number of employees involved closures, downsizing, upsizing and birth.

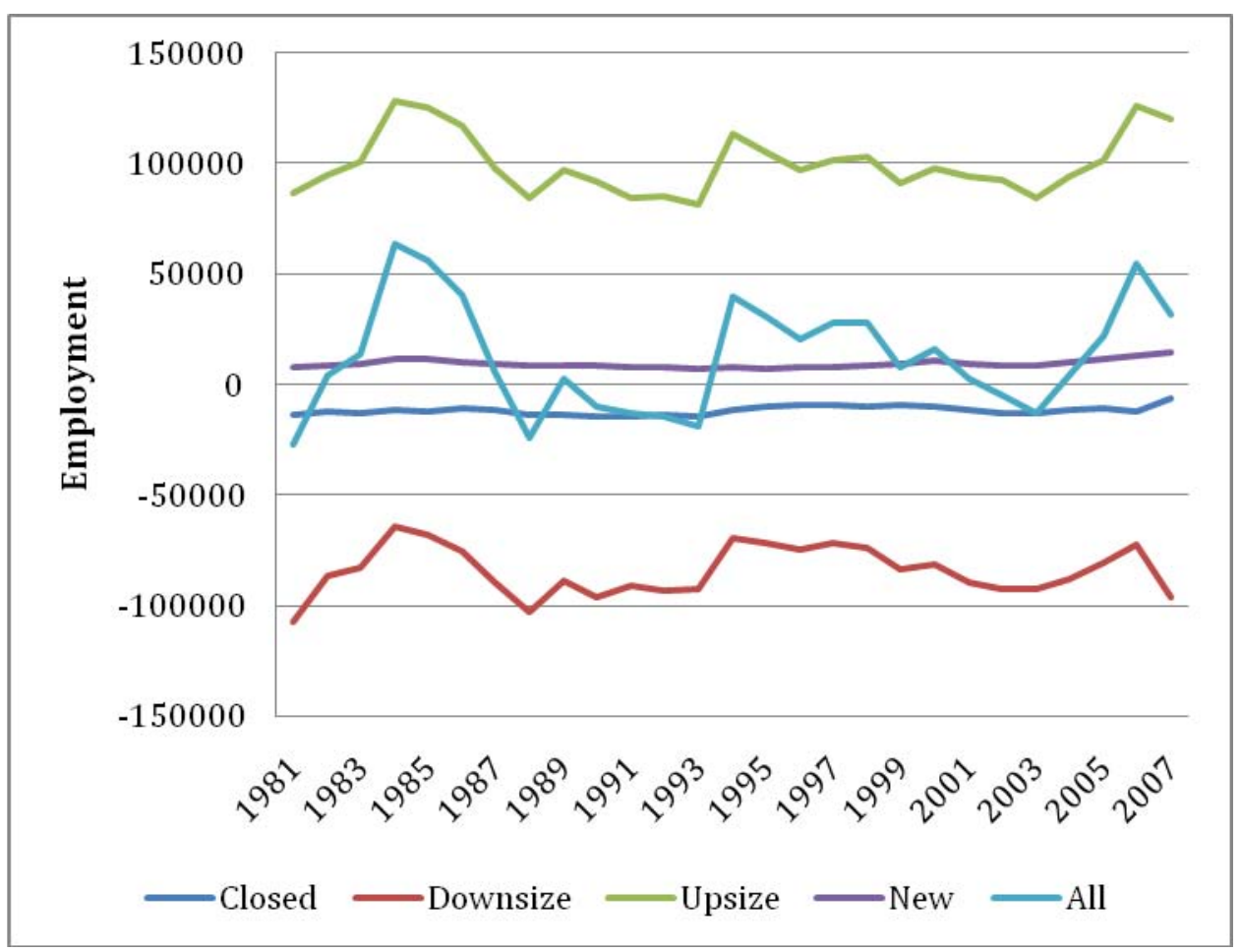

\section{Growth of firms}

We will now turn to the growth of employment and in particular ask the question which types of firms are responsible for the most of the job growth. Similar to Figure 7 above we can now construct Figure 8 on the growth of employment using the current size concept.

\footnotetext{
${ }^{6} \mathrm{All}$ job creation and destruction from merges and acquisitions are left out in the following since they will overstate creation and destruction, where in fact only the net creation from M\&A should apply. When splitting creation and destruction up into size and age, it is not possible to include M\&A as net creation and destruction in the year where it happens. 3.75\% of the firms are mother firms that take over another firm, have a spin-off, merge with other firms or split up into several firms. $1.3 \%$ of the firms are on average spin-offs including firms, that spin off as a private firm from a public firm. 0.5 of the firms are taken over by another firm.
} 


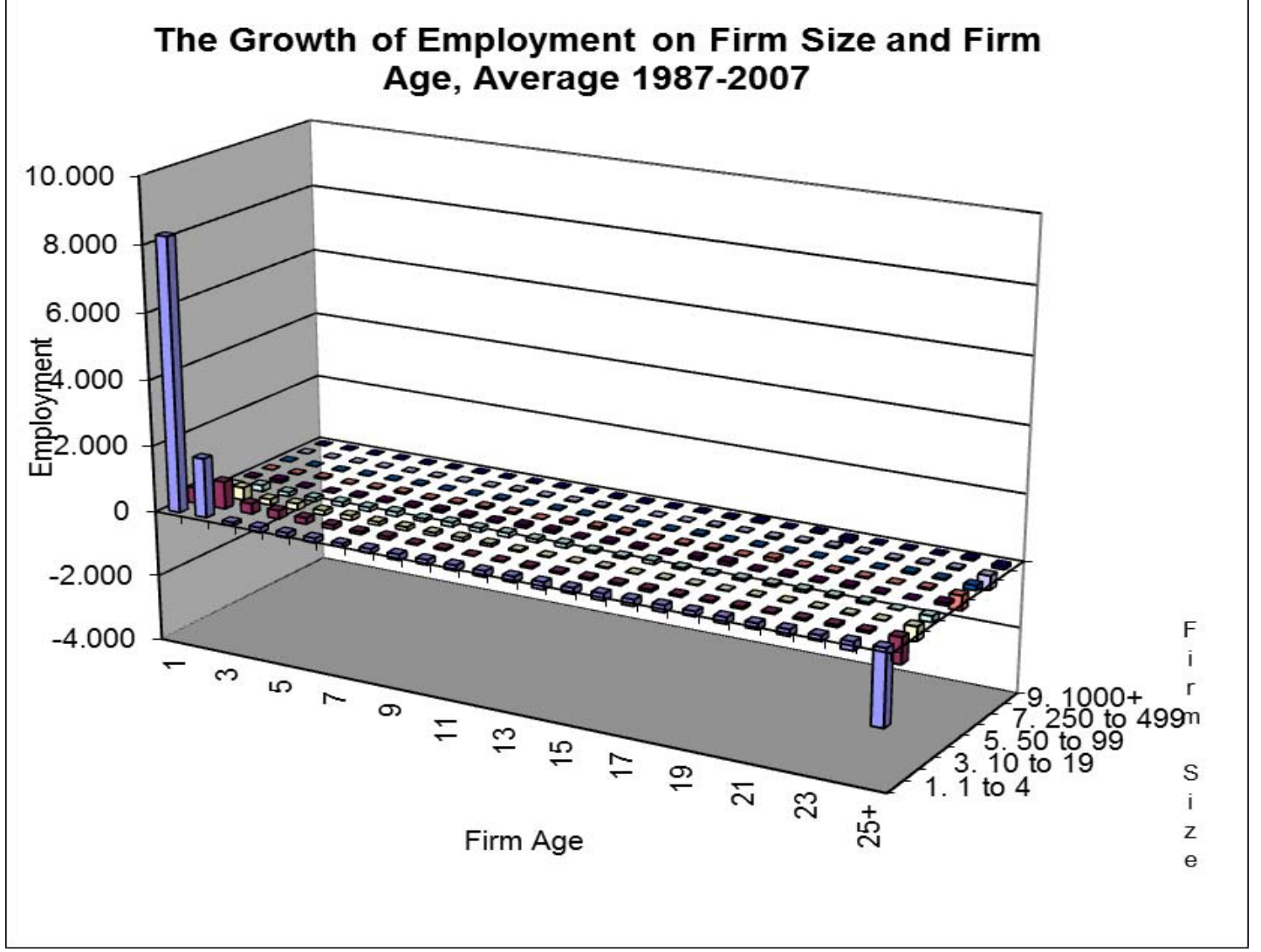

Figure 8 shows that young and small firms contribute most to the growth in employment, while the old and small contribute most to the net job destruction. Summing over all size groups creates the two dimensional picture of Figure 9.

Figure 9: Net Growth and Firm Age, Average 1987-2007

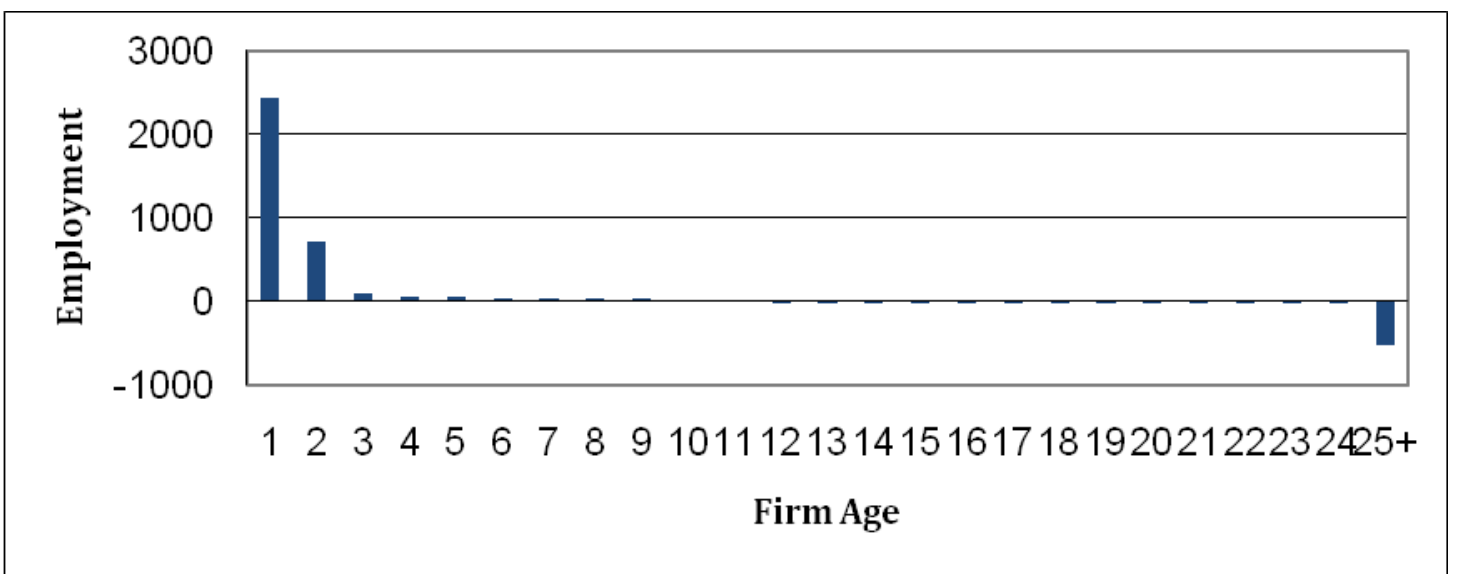




\section{Regressions}

Of course, these effects may differ between industries because some industries are net destroying jobs over the investigated period while others have been creating jobs. To make the decomposition, we will estimate the following equation by OLS:

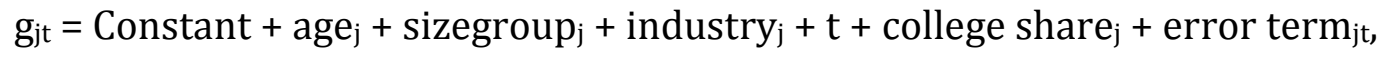

Where $\mathrm{g}$ is growth rate, $\mathrm{j}$ is firm and $\mathrm{t}$ is year.

We recall that the growth rate is measured as the base year growth (employment in $t$ divided with the employment in t-1) or alternatively as what is called current year growth (the growth defined as the number of jobs in $\mathrm{t}$ divided by the number of jobs in $\mathrm{t}-1$ plus the number of jobs in $\mathrm{t}$ ).

Age of the firm is divided into annual categories from 1 year to $15+$ years, where the last category covers all with ages 15 and above.

Sizegroup is the size of the employment of the firm divided into groups. The first is $1-4$ employees, then 5-9 employees, 10-19 etc. These groups are by construction not containing the same number of employees but the groups are chosen so that comparisons can be made with Haltiwanger et al.

Industry is divided into the 27 groupings of the ISIC code where some groups are put together due to their small size.

Finally, we have added a variable, college share that describes the human capital content of the firm. We have chosen the simple measure of the share of employees with further education defined as vocational training above the level of apprentice training. In praxis this is the share with college training and above for each firm. Danish firms are usually employing a mixture of non-skilled and skilled workers, where the latter all have an apprentice training consisting of 2.5 to 4 years of training on top of basic schooling. The number with further education has slowly increased over the years and was in 2002 about 17\% for the manufacturing industry and 13\% for trade (Eriksson et al, 2006).

We have applied the regression results in the next sections to analyze a number of issues. First, we have looked at the net job creation depending on age and size. We have in the text focused on current size concept as explained earlier. The graphs are constructed by using the 
relevant regression coefficients in Tables 2 to 6 . Since the coefficients are deviations from the left out category we have added the mean of the reference group before we have graphed the results.

\section{Size and Age}

The first graph, Figure 10 shows the overall job growth for firms. The graphs depict the coefficients to size with and without age controls. The other controls are the ones described in the specification presented earlier. The graph without age controls shows a U-formed relationship where small firms are active in creating new jobs and that activity is increasing with size except for the big companies where job creation falls to almost nothing.

Using current year growth definition, which seems to be the most reasonable and including controls for firm age makes the small firms inactive in creating more jobs because with age controls they are actually destroying more jobs than even bigger firms.This demonstrates clearly that the age element is dominating in the explanation of which firms creates most jobs.

Figure 10:Firm level net employment growth rates by firm size without M\&A

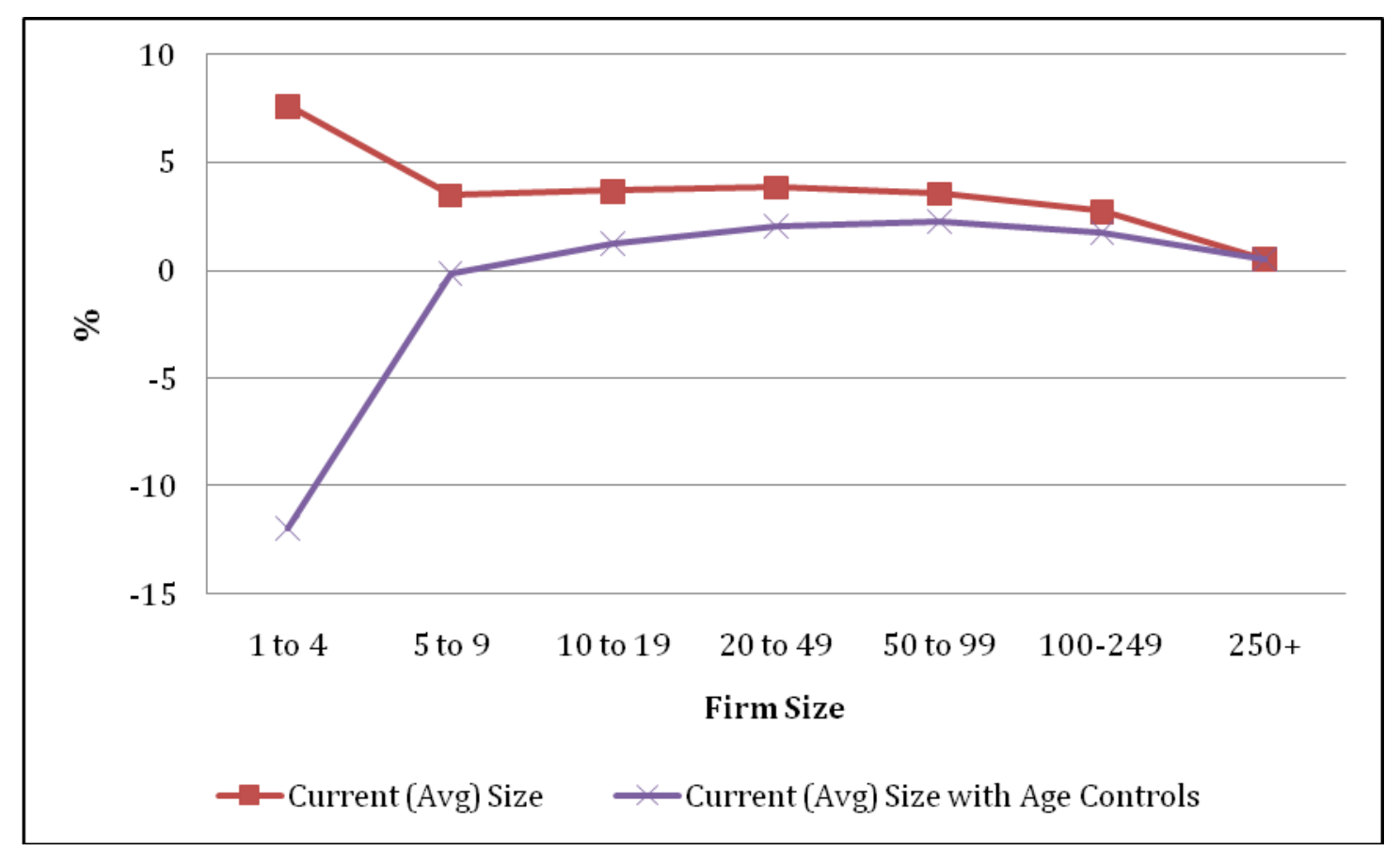

In Figure 11 we have excluded new firms and thus only have continuing and closed firms. We see that there remain no size differences as both curves are flat with respect to size. Thus, we may assume that the whole action lies in creation of new firms. 
Figure 11: Firm level net employment growth rate for continuing firms by firm size without M\&A

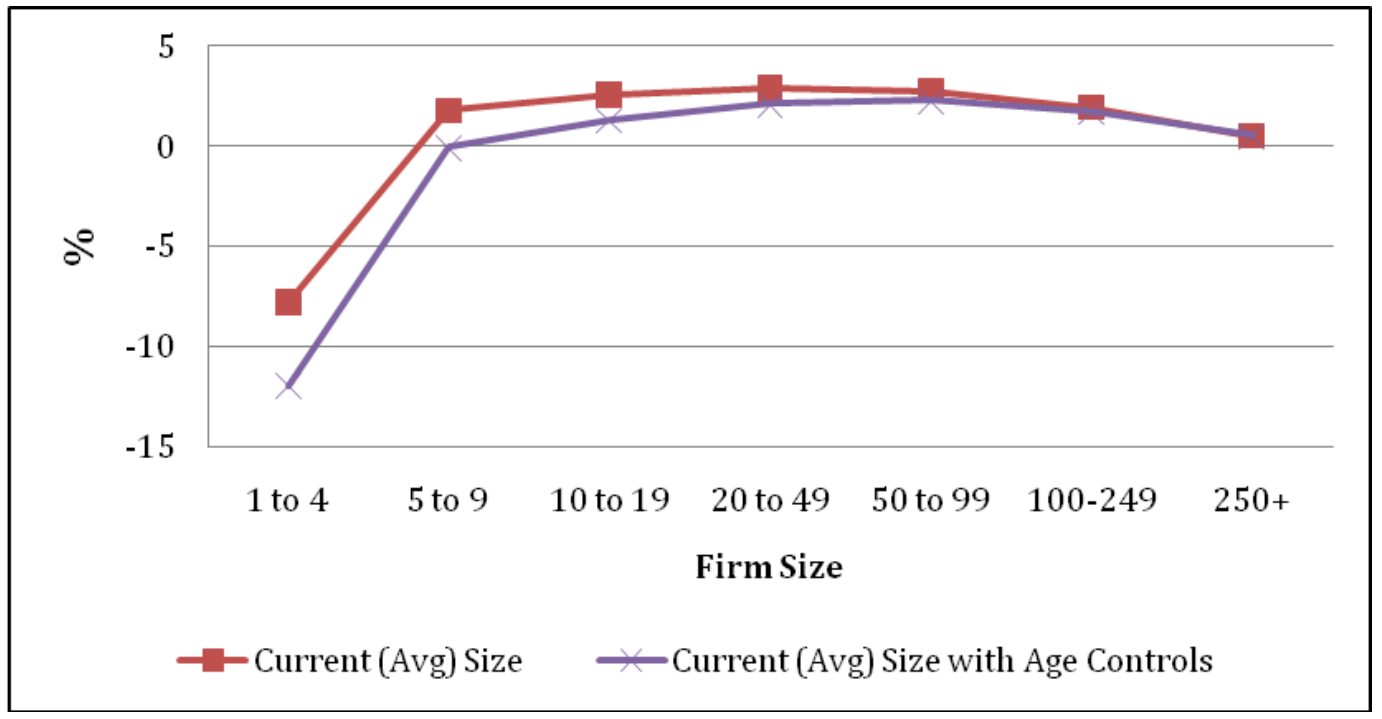

Since, size does not seem to play a big role we will now change to the age dimension. Thus, Figure 12 is similar to Figure 11 but now displays the age dimension. The picture is that the new and very young firms now make the largest positive contribution to job growth, while firms more than 3 years old have negative net growth. The oldest firms have the lowest net growth.

Figure 12: Firm level net employment growth by firm age without M\&A

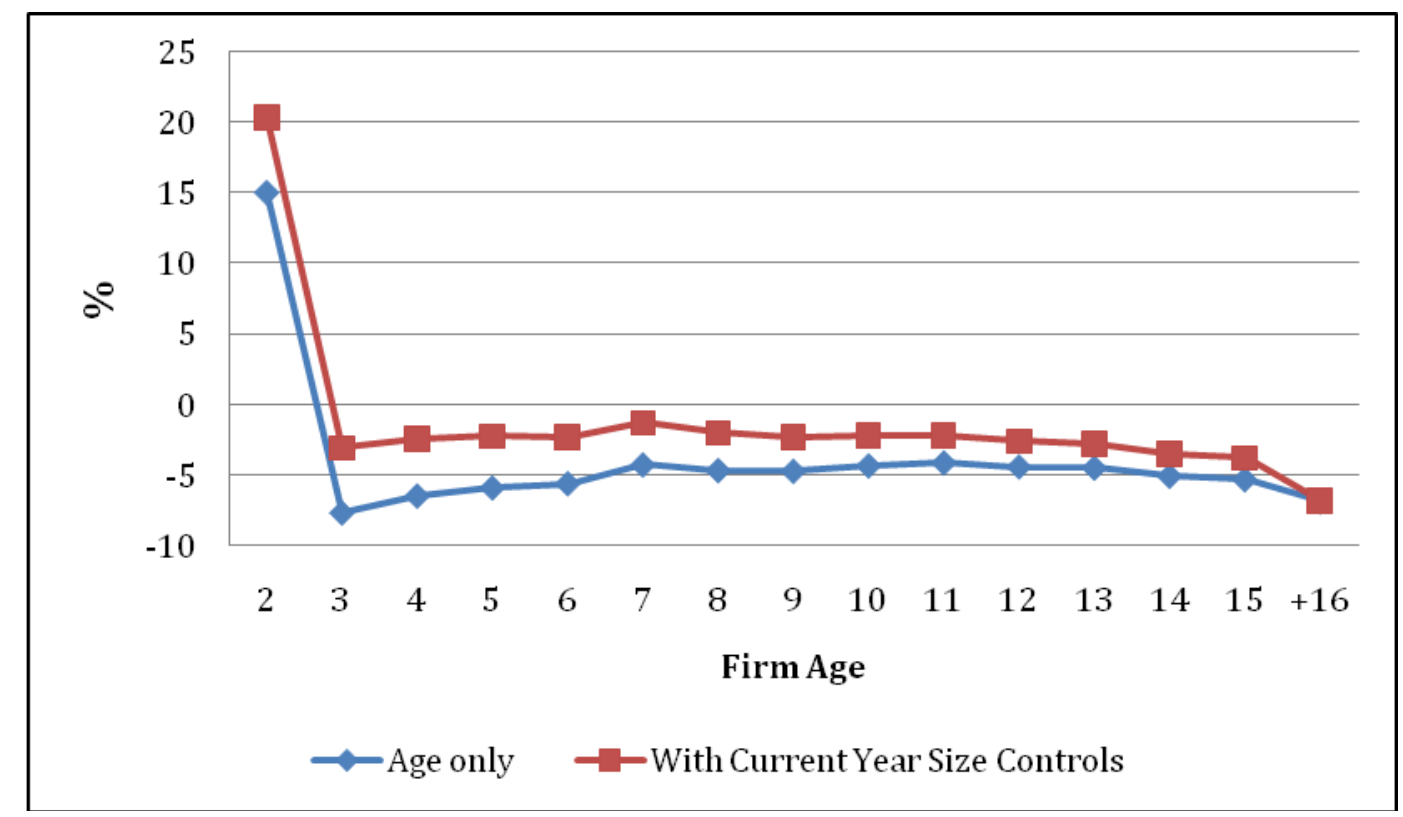

If we exclude new firms and close downs and concentrate on continuing firms, Figure 13, we can see that the 3 to almost 15 years old firms make a positive contribution to job growth 
provided they survive. In particular the young firms are subject to negative net growth due to closures.

Figure 13: Net employment growth for continuing firms by firm age without M\&A

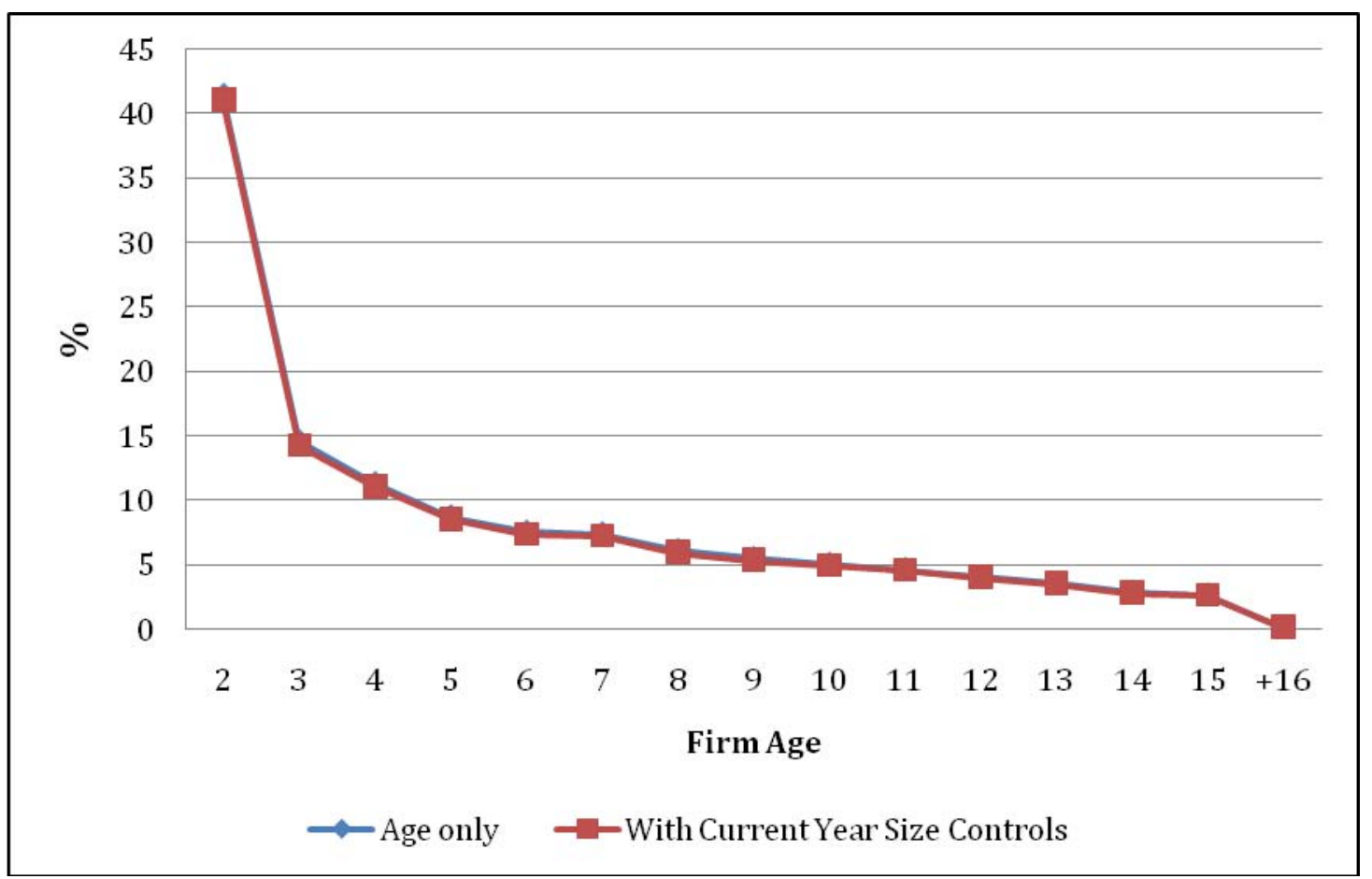

In Figure 13 there is very little difference between the curve with age only and the curve with size controls. The main picture for these continuing firms is that net job creation is large for the new firms but it drops relatively quickly with age, so that it becomes very modest for $15+$ firms.

\section{Discussion}

Comparing with the U.S. in Haltiwanger et al we find that the net employment for all firms has about the same look in the two countries, but the level is different. Where there is a small but positive contribution from all young firms in the US, there is only a positive contribution from the 2 years old in Denmark. However, when we exclude all the closed firms and only focus on the continuing firms as in Figure 13 and compare that with a similar graph for the U.S. we see the same pattern. The reason is simply that closures take a bigger toll on younger firms in Denmark than in the U.S. 


\section{Job creation}

We will now look at the job creation and destruction activity of those firms that are discontinuing. We will now look at the job creation and destruction separately. Thus, Figure 14 shows the job creation in firms that are either new or upsizing. The graphs show that they are relatively active in creating jobs even when new and that this ability only is slowly weakened with firm age.

Figure 14: Job Creation New and Upsizing Firms by Firm Age without M\&A

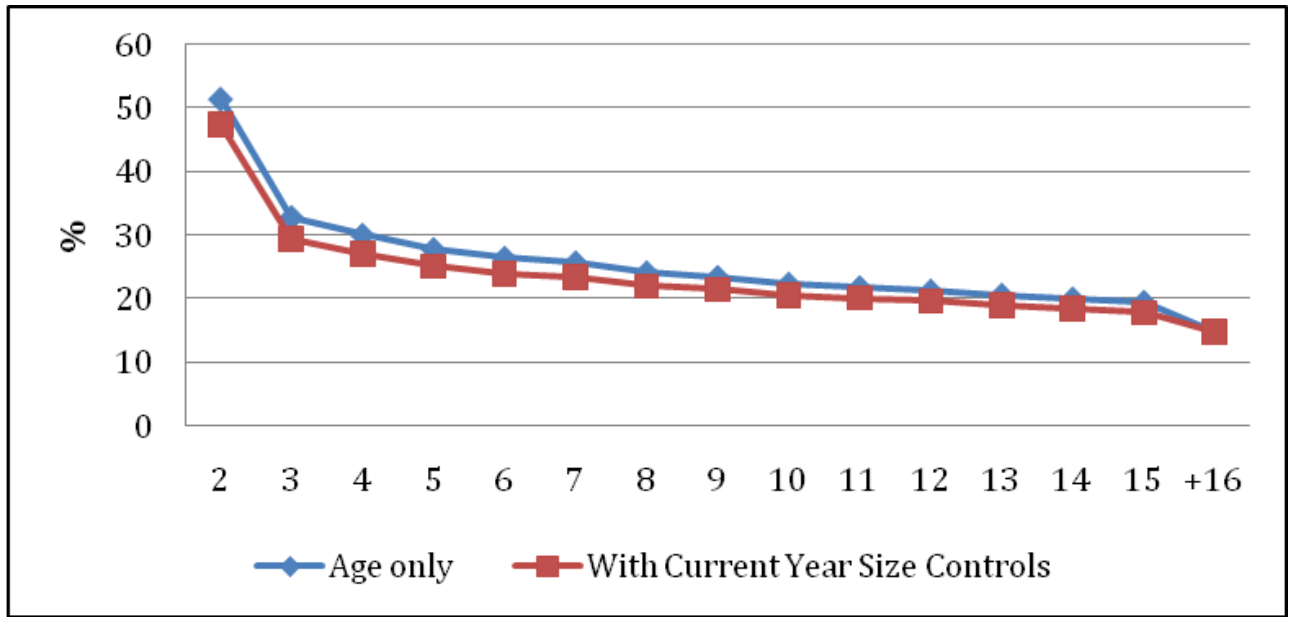

Similarly, we have looked at the destruction of jobs for the same group of firms. Figure 15 shows that they are even more active in destroying jobs. Comparing Figures 14 and 15 we can see that young firms that are eventually closing down are indeed very active but within a downward and deadly spiral.Thus, we can conclude that young firms are highly active in both creating and destroying jobs.

Figure 15: Job Destruction Closed and downsizing Firms by Firm Age without M\&A

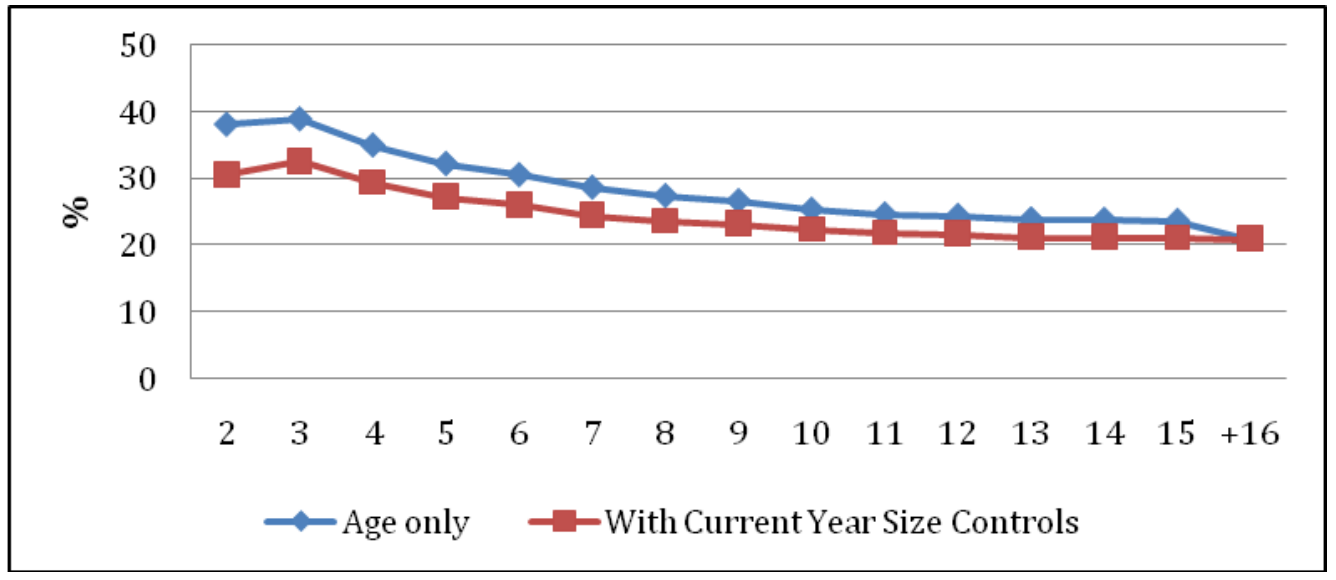


Figure 16 shows job destruction by closing firms. It is evident, that young firms have a much higher risk of closure than older firms.

Figure 16: Job destruction from firm exit by firm age

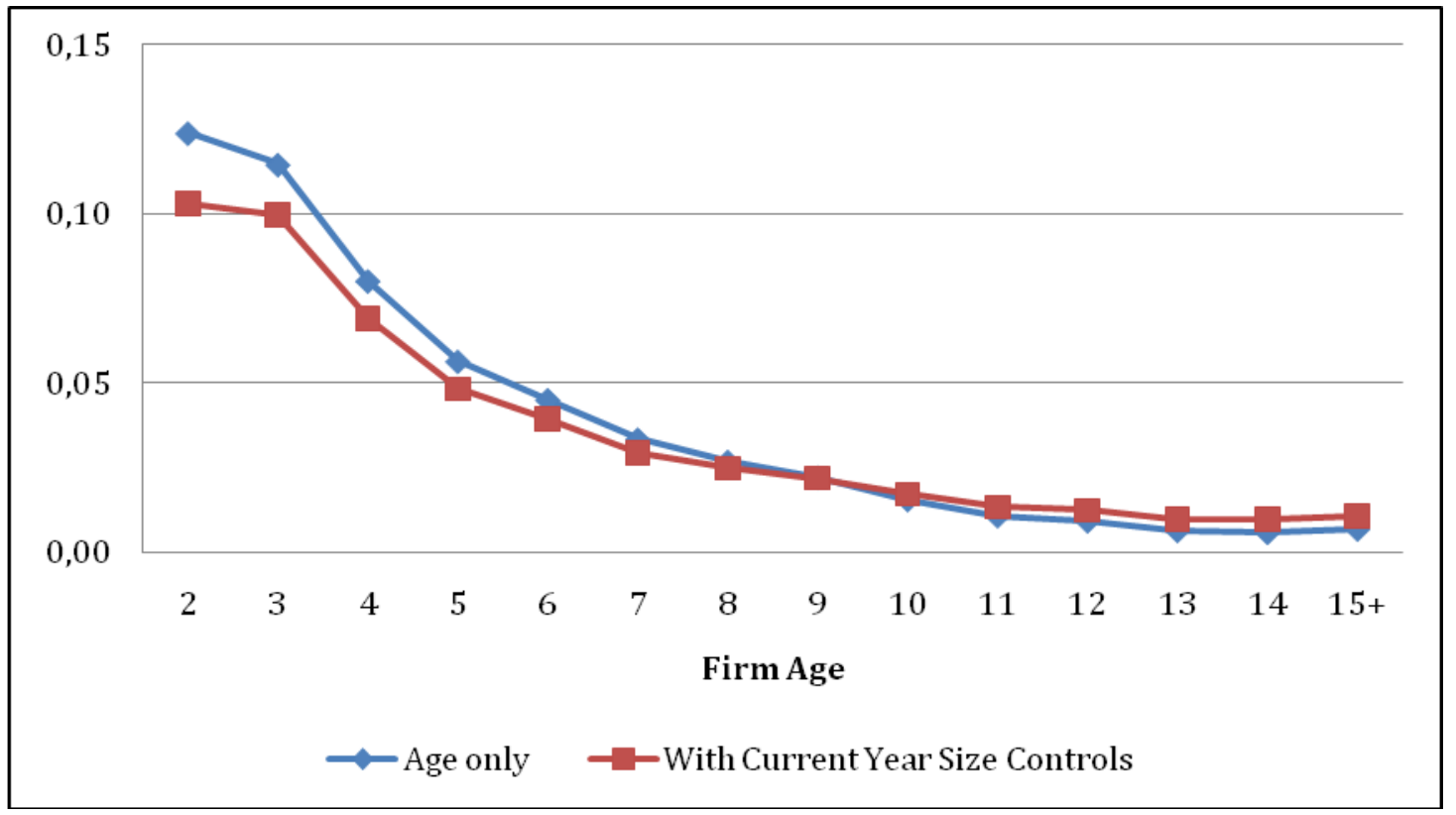

\section{Discussion}

Thus, our results show clearly that it is age and not size that is the important determinant. Furthermore, the results show that young firms are creating and destroying more jobs than older firms, though they are still creating more than destroying provided that they survive. The reason why there is a general understanding that small firms are more important for the job creation is of course that most young firms have started out as small. The point made here is that many small firms never grow larger and when they grow larger it is usually when they are young. Similarly, it is found that the small firms are actually destroying many jobs when they get old probably as part of their life cycle. 
It is important to bear in mind that the regressions and the graphs show the predicted growth per firm of a specific age and size etc. Thus, our results show that given there is a young firm it will be more active in creating new jobs than older firms. Now this is of course not the same as saying that all new jobs are created by young firms since older firms are also creating new jobs, just with a lower rate. But because there are more old firms ( $>15$ years old) they still count for a substantial part of the total job creation. If there were only one new and young firm, and it was as active creating jobs as we predict, it could only be responsible for a tiny proportion of the total job creation. So the total impact will depend on how many new firms are created and on how many of these firms that survive the first years.

Figure 3 showed that only 20\% of all firms in Denmark were younger than 15 years. The similar number for the U.S. is 35\%, Haltiwanger et al, 2006. That means that Denmark has a smaller number of young firms to grow from than USA. We still need to see if this is a special feature of the U.S. economy or it is a special feature of the Danish economy. But irrespective of the answer the small number of young firms surviving long enough to create employment seems to be the real weak point in Denmark.

\section{Other results}

Finally, we will now comment on some of the other regression results. We have in all the regressions reported in Tables 2-6 included the proportion of employees at the firm level with further education, which is those with more than an apprentice training. We have also included industry variables and calendar time that will pick up business cycles.

\section{Human Capital}

The indicator for further education in Tables 2 to 6 shows that the higher the proportion with further education, (college training and above) the higher the net growth in jobs, see Table 1. The coefficients should be interpreted as proportions, where 0.19 means 19\% higher job creation in firms with more employees with further education. Thus, if the proportion of employees with completed college training increases with 10 percentage points creation increases with $1.9 \%$. 


\begin{tabular}{llrr}
\hline & & College training & Std.dev \\
\hline All firms & Net growth & $\mathbf{0 . 1 8 6 3}$ & 0.0022 \\
Continuing firms & Net growth & $\mathbf{0 , 2 2 3 4}$ & 0,0022 \\
Firm exits & J ob destruction & $\mathbf{0 . 0 0 5 7}$ & 0.0010 \\
New or upsizing & J ob creation & $\mathbf{0 . 1 0 1 7}$ & 0.0013 \\
Closed or downsizing & J ob destruction & $\mathbf{- 0 . 1 4 8 5}$ & 0.0013 \\
\hline
\end{tabular}

Note: Continuing firms are without new and closed

Table 1 shows that this effect is even stronger for continuing firms and that the number of jobs destroyed due to closed or downsizing firms is also smaller when the human capital indicator is high. Furthermore, job creation is less high for new or upsizing firms and job destruction rates are lower the more educated the workforce is.

These results show with utmost clarity that the level of training matters for job creation. Firms with higher trained work forces are simply better to create growth in jobs even when controlling for age, size and industry.

\section{Industry differences}

In Figure 17 we have reported the industry differences in job creation and destruction for the whole period. The numbers reported in the figure are average effects over the entire period compared with the base industry, trade. It is remarkable, that most industries are actually creating more jobs than they destroy and most industries are creating and destroying more than trade with textile as the usual winner of job destruction. Hotels and tele (communication) both has high destruction rates but they are also having large creation rates. Using these average figures hides of course relative movements within the period.

Figure 17. Industry differences in job creation and destruction.

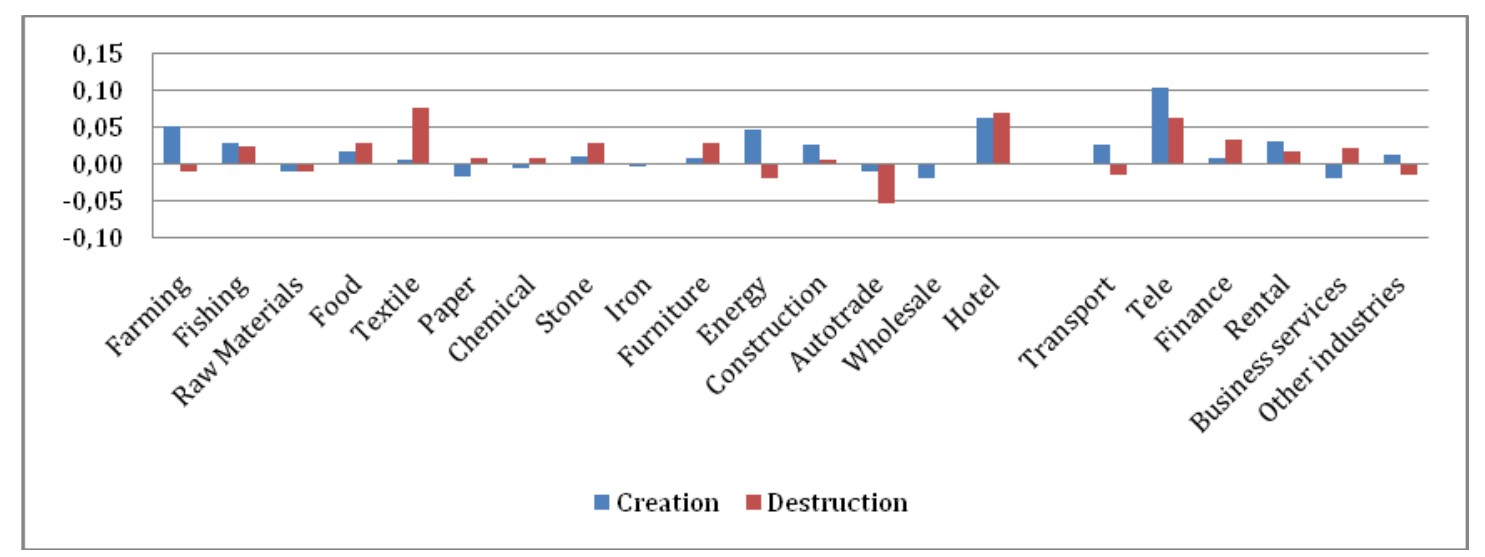


The coefficients from the net growth regression are similarly displayed in Figure 18. (These numbers are not totally identical to the differences between job destruction and creation in Figure 17 because they come from two different regressions.)

Figure 18: Net growth by industry based on regressions.

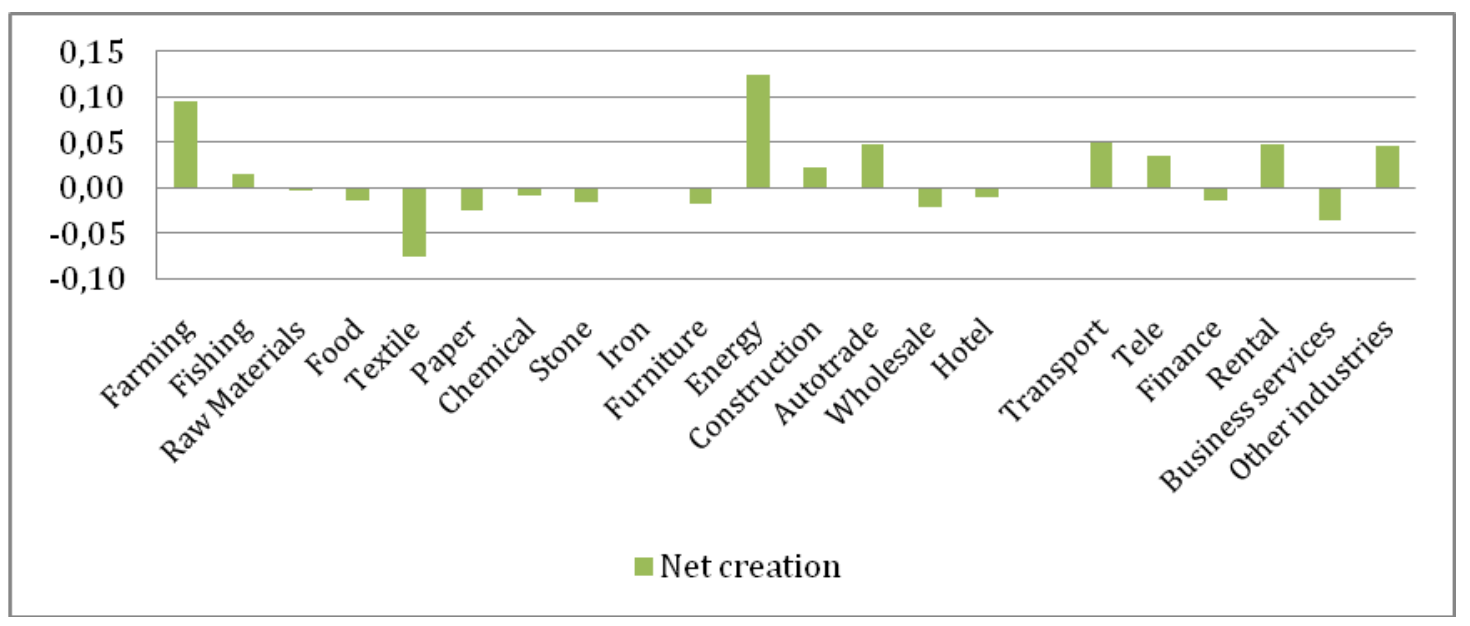

The interpretation of each column in the above histograms is the net growth compared to Trade when we have controlled for business cycles, size and age of the firms. The largest percentage growth is found in Energy followed by Farming. The other big ones are Auto trade, Rental and Transportation.

\section{Business cycles}

Similarly to the graphs above we have constructed a graph from the estimated time dummies.

First we have used the coefficients from the job creation and destruction regressions and the results are reported in Figure 19. Since the regressions had 2006 as base year the graph shows the job creation and destruction as deviations from 2006 and because 2006 was a high growth year with a high level of creations as of destructions all the other years come out with negative figures. However the graph still shows the effect of business cycles.

First, it is remarkable that job creation and destruction are so stable over time. Second, the upswing in the economy from 1982 is clearly seen as increasing creation and decreasing destructions. Similarly, the recession in 1988 means that creation goes down and destructions goes up. From then on creation goes up and destructions go slowly down until the upswing in 1994 where both tendencies are re-enforced. Creations are then slowing down and destructions slowly rising until 2002 where a new upswing in creations and similar 
downswing in destructions start. 2006 is a rare year because both creations and destructions are relatively high.

Figure 19. Job creation and destruction over the business cycle.

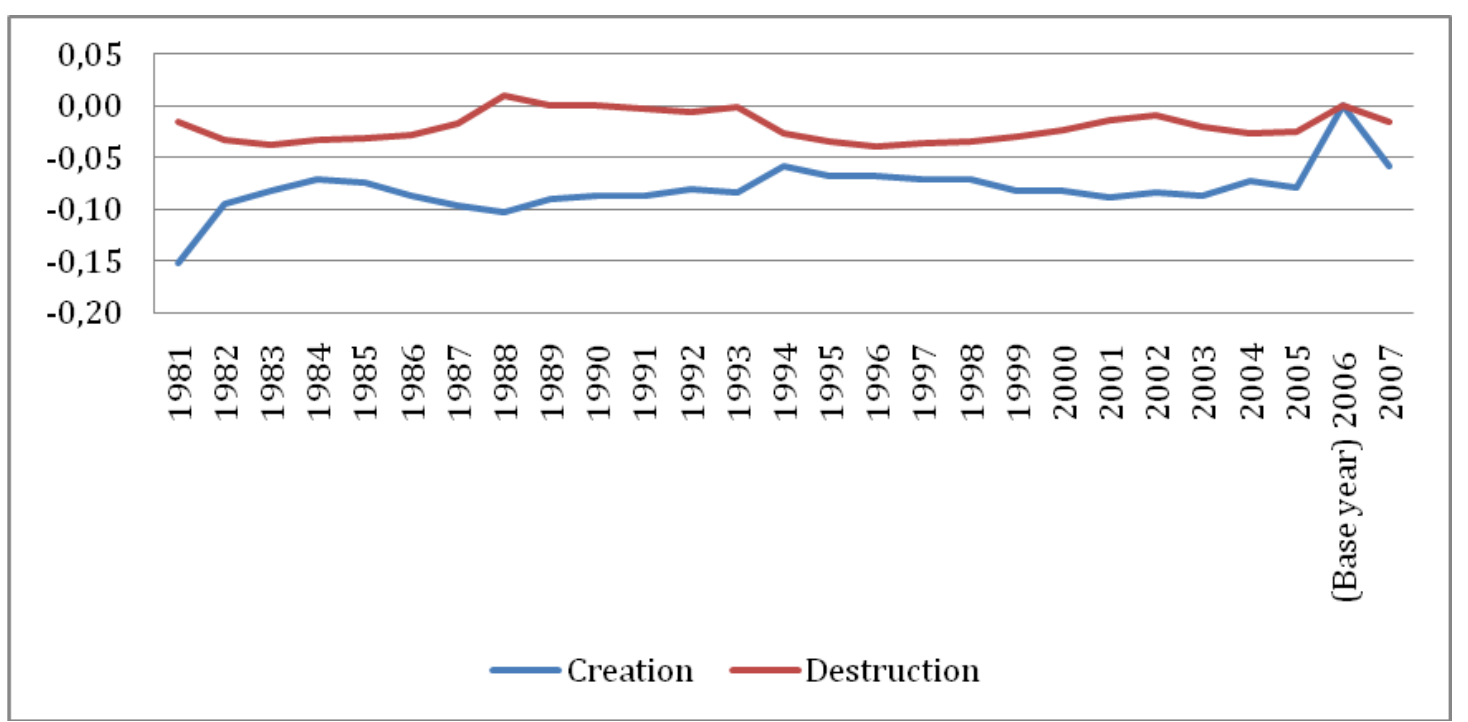

Finally, we have also looked at the net creation as it comes out of the regression on net growth. Basically, we see the same pattern as above.

Figure 20. Net job creation over the business cycle based on regressions. 


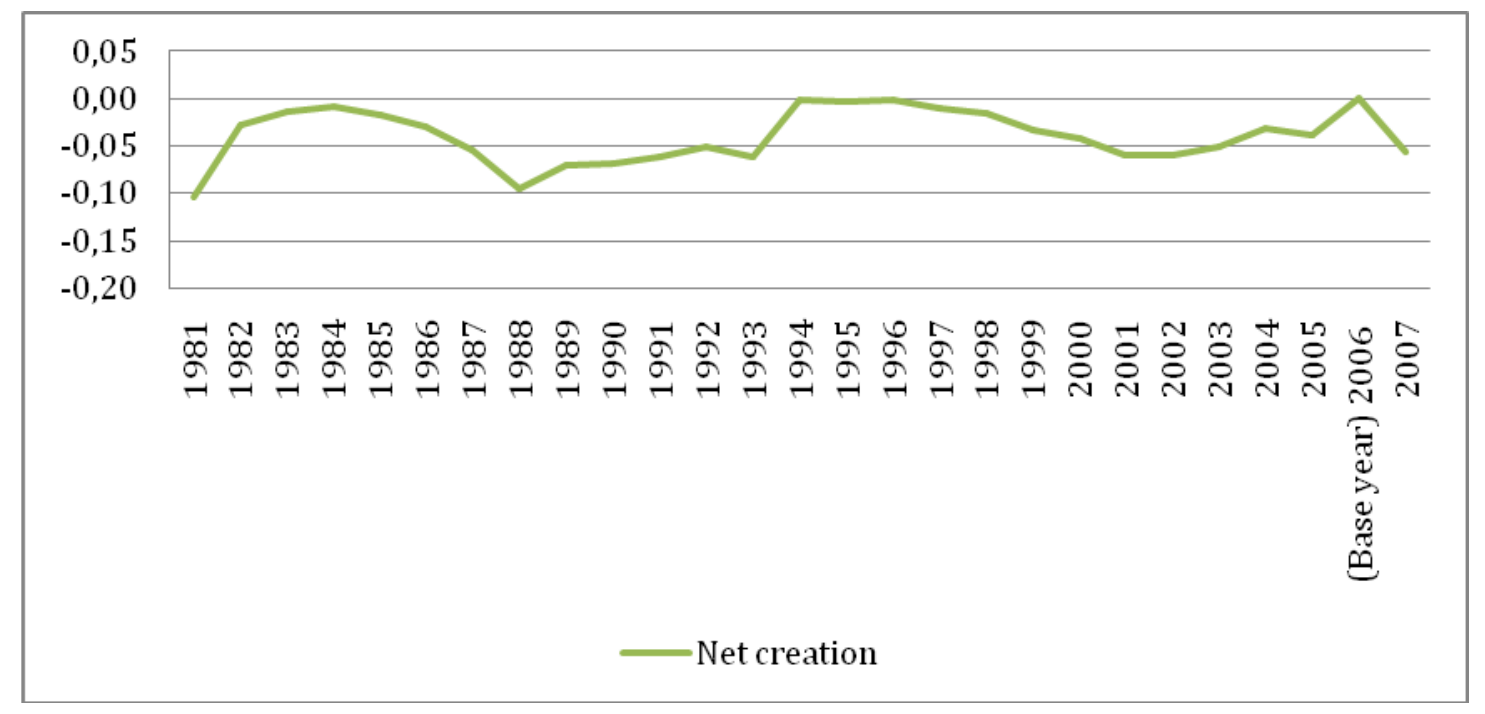

\section{Discussion}

The results are in most dimensions in line with the previous results for Denmark when you take into account that we have made the transition to firms. We have in the paper tried to be as close as possible to Haltiwanger et al, 2010 with respect to definitions so their results should be comparable. We remind that there are a couple of aspects that makes the Danish definitions different. First, we are not able to identify enterprise groups where several firms are considered as one. Second, we have treated the acquisition of a workplace differently as we have let it retain the experience it already had where Haltiwanger et al consider it as reborn. Finally, we have a variable for human capital content. None of these should change the main results, since the first two seems to draw results in two different directions.

Haltiwanger et al do also find that age is the most important dimension of job growth. Furthermore, the growths for continuing firms look almost completely like the similar graph in Haltiwanger et al. The only difference seems to be that the first year growth is higher in Denmark. The same is the case for the gross job creation and destruction for the eventually closed and downsizing firms. So the mechanisms are much the same in the U.S. and Denmark. But comparing with the U.S. though we find that the net employment for all firms has about the same look in the two countries, the level is different. Where there is a small but positive contribution from all young firms in the U.S., there is only a positive contribution from the 1 to 2 years old firms in Denmark. The main reason seems to be that the young firms in Denmark have a substantially higher death rate than in the U.S. 


\section{Conclusion}

This study has made an extensive attempt to construct data for firms to account for the fledgling identity of a firm over time in order to construct the units necessary to follow a firm over time and to establish the age of the firm. The definitions are to a large extent identical to those used in Haltiwanger et al, 2010. The data work deviates from earlier attempts to follow firms in Denmark, Dahl et al. However, a few issues have not been fully solved yet. One is that there is no indicator in the Danish data for enterprise groups, which covers a number of firms and make up an administrative and legal entity. Such indicators exist for the U.S. Another is that we have still excluded mergers and acquisitions at the firm level, though we have included change of ownership of workplaces.

This study has shown that carefully defined firm job growth is mostly dependent on the age of firms. Young firms are much more active creating more new jobs than older firms. Unfortunately, they are also more active destroying jobs. However, the net contribution of young firms to job growth is positive. This is to a large extent as in the U.S.,seeHaltiwanger et al, 2010). But the difference is that Denmark does not have so many continuing young firms with the result that a smaller fraction of all new jobs created come from the young firms in Denmark. The reason may be that fewer firms with employees are created in Denmark compared to the U.S. or that fewer of these survive the first years.

This investigation raises a number of questions for further research. One is what is it that determines if a young company survives and grows. Are there any factors that can be identified that facilitate survival? Are some industries more likely to produce new starting firms that cannot survive or grow than others?

\section{References}

Haltiwanger, John T, Ron Jarmin and Javier Miranda, Who creates jobs?Small versuslarge versus young, Working Paper 16300, NBER.

Dahl, M. S., Jensen, P. G., \& Nielsen, K. (2009). Jagten på fremtidens nye vækstvirksomheder: Resumé (1 udg.) København: Jurist- og Økonomforbundets Forlag.

Eriksson, Tor, Rikke Ibsen, Jingkun Li og Niels Westergård-Nielsen, Globalisering og det danske arbejdsmarked, Jurist og Økonomforbundets Forlag, København, 2006. 
Lazear, Edward and Kathryn Shaw (eds), The Structure of Wages, National Bureau of Economic Research, Chicago 2008

Davis, Steven, John Haltiwanger and Scott Schuh, Job Creation and Destruction, MIT 1997

Hethey, Tanja and Johannes Schmieder, Using Worker Flows in the Analysis of Establishment Turnover - Evidence from German Administrative Data, WP Research Data Centre (FDZ) of the German Federal Employment Agency at IAB, 2010

Dunne, Timothy, Mark Roberts and Larry Samuelson, The Growth and Failure of U.S. Manufacturing Plants, The Quarterly Journal of Economics, Vol 104, No 4, Nov 1989, pp 671698. 
Table 2. Firm Level Net Employment Growth Rates without M\&A

\begin{tabular}{|c|c|c|c|c|c|c|c|c|c|c|}
\hline & \multicolumn{2}{|c|}{ Base Year Size } & \multicolumn{2}{|c|}{ Current (Avg) Size } & \multicolumn{2}{|c|}{ Age Only } & \multicolumn{2}{|c|}{$\begin{array}{c}\text { Base Year Size } \\
\text { with Age Controls }\end{array}$} & \multicolumn{2}{|c|}{\begin{tabular}{|l|} 
Current (Avg) Size \\
with Age Controls
\end{tabular}} \\
\hline & Cofficient & Std.err & Cofficient & Stdr. & Cofficient & Stdr. & Cofficient & Stdr. & Cofficient & Stdr. \\
\hline College_Share & 0,14 & 0,0019 & 0,25 & 0,0025 & 0,19 & 0,0022 & 0,11 & 0,0018 & 0,19 & 0,0022 \\
\hline Size1 to 4 & 0,16 & 0,0022 & 0,07 & 0,0029 & & & 0,06 & 0,0022 & $-0,12$ & 0,0027 \\
\hline Size5 to 9 & 0,00 & 0,0024 & 0,03 & 0,0031 & & & $-0,03$ & 0,0023 & $-0,01$ & 0,0028 \\
\hline Size10 to 19 & 0,00 & 0,0026 & 0,03 & 0,0034 & & & $-0,02$ & 0,0025 & 0,01 & 0,0031 \\
\hline Size20 to 49 & 0,00 & 0,0029 & 0,03 & 0,0038 & & & $-0,01$ & 0,0028 & 0,02 & 0,0034 \\
\hline Size50 to 99 & $-0,01$ & 0,0042 & 0,03 & 0,0056 & & & $-0,01$ & 0,0041 & 0,02 & 0,0050 \\
\hline Size 100 to 249 & $-0,01$ & 0,0055 & 0,02 & 0,0072 & & & $-0,02$ & 0,0053 & 0,01 & 0,0065 \\
\hline Size +250 & & & & & & & & & & \\
\hline Age_1 & & & & & 2,07 & 0,0024 & 0,95 & 0,0020 & 2,13 & 0,0024 \\
\hline Age_2 & & & & & 0,22 & 0,0022 & 0,25 & 0,0018 & 0,27 & 0,0023 \\
\hline Age_3 & & & & & $-0,01$ & 0,0023 & 0,05 & 0,0019 & 0,04 & 0,0024 \\
\hline Age_4 & & & & & 0,00 & 0,0024 & 0,04 & 0,0020 & 0,04 & 0,0025 \\
\hline Age_5 & & & & & 0,01 & 0,0025 & 0,04 & 0,0021 & 0,05 & 0,0025 \\
\hline Age_6 & & & & & 0,01 & 0,0026 & 0,03 & 0,0021 & 0,05 & 0,0026 \\
\hline Age_7 & & & & & 0,03 & 0,0026 & 0,04 & 0,0021 & 0,06 & 0,0026 \\
\hline Age_8 & & & & & 0,02 & 0,0027 & 0,03 & 0,0022 & 0,05 & 0,0027 \\
\hline Age_9 & & & & & 0,02 & 0,0027 & 0,03 & 0,0022 & 0,05 & 0,0027 \\
\hline Age_10 & & & & & 0,03 & 0,0028 & 0,03 & 0,0023 & 0,05 & 0,0028 \\
\hline Age_11 & & & & & 0,03 & 0,0028 & 0,03 & 0,0023 & 0,05 & 0,0028 \\
\hline Age_12 & & & & & 0,02 & 0,0028 & 0,03 & 0,0023 & 0,04 & 0,0028 \\
\hline Age_13 & & & & & 0,02 & 0,0028 & 0,03 & 0,0023 & 0,04 & 0,0028 \\
\hline Age_14 & & & & & 0,02 & 0,0029 & 0,02 & 0,0024 & 0,03 & 0,0029 \\
\hline Age_15 & & & & & 0,02 & 0,0029 & 0,02 & 0,0024 & 0,03 & 0,0029 \\
\hline$R^{\wedge} 2$ & 0,03 & & 0,01 & & 0,19 & & 0,10 & & 0,20 & \\
\hline$N$ & 3.336 .236 & 3.336 .236 & 3.336 .236 & 3.336 .236 & 3.336.236 & 3.336 .236 & 3.336 .236 & 3.336 .236 & 3.336 .236 & 3.336 .236 \\
\hline
\end{tabular}


Table 3.Firm Level Net Employment Growth Rate for Continuing Firms without M\&A

\begin{tabular}{|c|c|c|c|c|c|c|c|c|c|c|}
\hline & \multicolumn{2}{|c|}{ Base Year Size } & \multicolumn{2}{|c|}{ Current (Avg) Size } & \multicolumn{2}{|c|}{ Age Only } & \multicolumn{2}{|c|}{\begin{tabular}{|c|} 
Base Year Size \\
with Age Controls
\end{tabular}} & \multicolumn{2}{|c|}{\begin{tabular}{|l} 
Current (Avg) Size \\
with Age Controls
\end{tabular}} \\
\hline & Cofficient & Std.err & Cofficient & Stdr. & Cofficient & Stdr. & Cofficient & Stdr. & Cofficient & Stdr. \\
\hline College_Share & 0,13 & 0,0020 & 0,21 & 0,0024 & 0,21 & 0,0024 & 0,13 & 0,0020 & 0,21 & 0,0024 \\
\hline Size1 to 4 & 0,10 & 0,0022 & $-0,08$ & 0,0028 & & & 0,10 & 0,0022 & $-0,08$ & $0,002 \varepsilon$ \\
\hline Size5 to 9 & $-0,02$ & 0,0024 & 0,01 & 0,0029 & & & $-0,02$ & 0,0024 & 0,01 & 0,0029 \\
\hline Size 10 to 19 & $-0,01$ & 0,0026 & 0,02 & 0,0032 & & & $-0,01$ & 0,0026 & 0,02 & 0,0032 \\
\hline Size 20 to 49 & $-0,01$ & 0,0029 & 0,02 & 0,0035 & & & $-0,01$ & 0,0029 & 0,02 & 0,0035 \\
\hline Size50 to 99 & $-0,01$ & 0,0042 & 0,02 & 0,0052 & & & $-0,01$ & 0,0042 & 0,02 & 0,0052 \\
\hline Size 100 to 249 & $-0,01$ & 0,0055 & 0,01 & 0,0067 & & & $-0,01$ & 0,0055 & 0,01 & 0,0067 \\
\hline \multicolumn{11}{|l|}{ Size +250 } \\
\hline Age_1 & & & & & & & & & & \\
\hline Age_2 & & & & & 0,22 & 0,002 & 0,25 & 0,0019 & 0,27 & 0,0023 \\
\hline Age_3 & & & & & $-0,01$ & 0,002 & 0,05 & 0,0020 & 0,04 & 0,0024 \\
\hline Age_4 & & & & & 0,00 & 0,002 & 0,04 & 0,0021 & 0,04 & 0,0025 \\
\hline Age_5 & & & & & 0,01 & 0,003 & 0,04 & 0,0021 & 0,05 & 0,0026 \\
\hline Age_6 & & & & & 0,01 & 0,003 & 0,03 & 0,0022 & 0,05 & 0,0026 \\
\hline Age_7 & & & & & 0,03 & 0,003 & 0,04 & 0,0022 & 0,06 & 0,0027 \\
\hline Age_8 & & & & & 0,02 & 0,003 & 0,03 & 0,0022 & 0,05 & 0,0027 \\
\hline Age_9 & & & & & 0,02 & 0,003 & 0,03 & 0,0023 & 0,05 & $0,002 \varepsilon$ \\
\hline Age_10 & & & & & 0,03 & 0,003 & 0,03 & 0,0023 & 0,05 & $0,002 \varepsilon$ \\
\hline Age_11 & & & & & 0,03 & 0,003 & 0,03 & 0,0023 & 0,05 & 0,0029 \\
\hline Age_12 & & & & & 0,03 & 0,003 & 0,03 & 0,0023 & 0,04 & 0,0029 \\
\hline Age_13 & & & & & 0,02 & 0,003 & 0,03 & 0,0024 & 0,04 & 0,0029 \\
\hline Age_14 & & & & & 0,02 & 0,003 & 0,02 & 0,0024 & 0,03 & 0,0030 \\
\hline Age_15 & & & & & 0,02 & 0,003 & 0,02 & 0,0025 & 0,03 & 0,0030 \\
\hline$R^{\wedge} 2$ & 0,01 & & 0,01 & & 0,01 & & 0,02 & & 0,01 & \\
\hline $\mathrm{N}$ & 3.336 .236 & 3.336 .236 & 3.336 .236 & 3.336 .236 & 3.336 .236 & 3.336 .236 & 3.189.624 & 3.189 .624 & 3.189 .624 & 3.189 .624 \\
\hline
\end{tabular}


Table 4. Job Destruction from Firm Exit by Firm Age

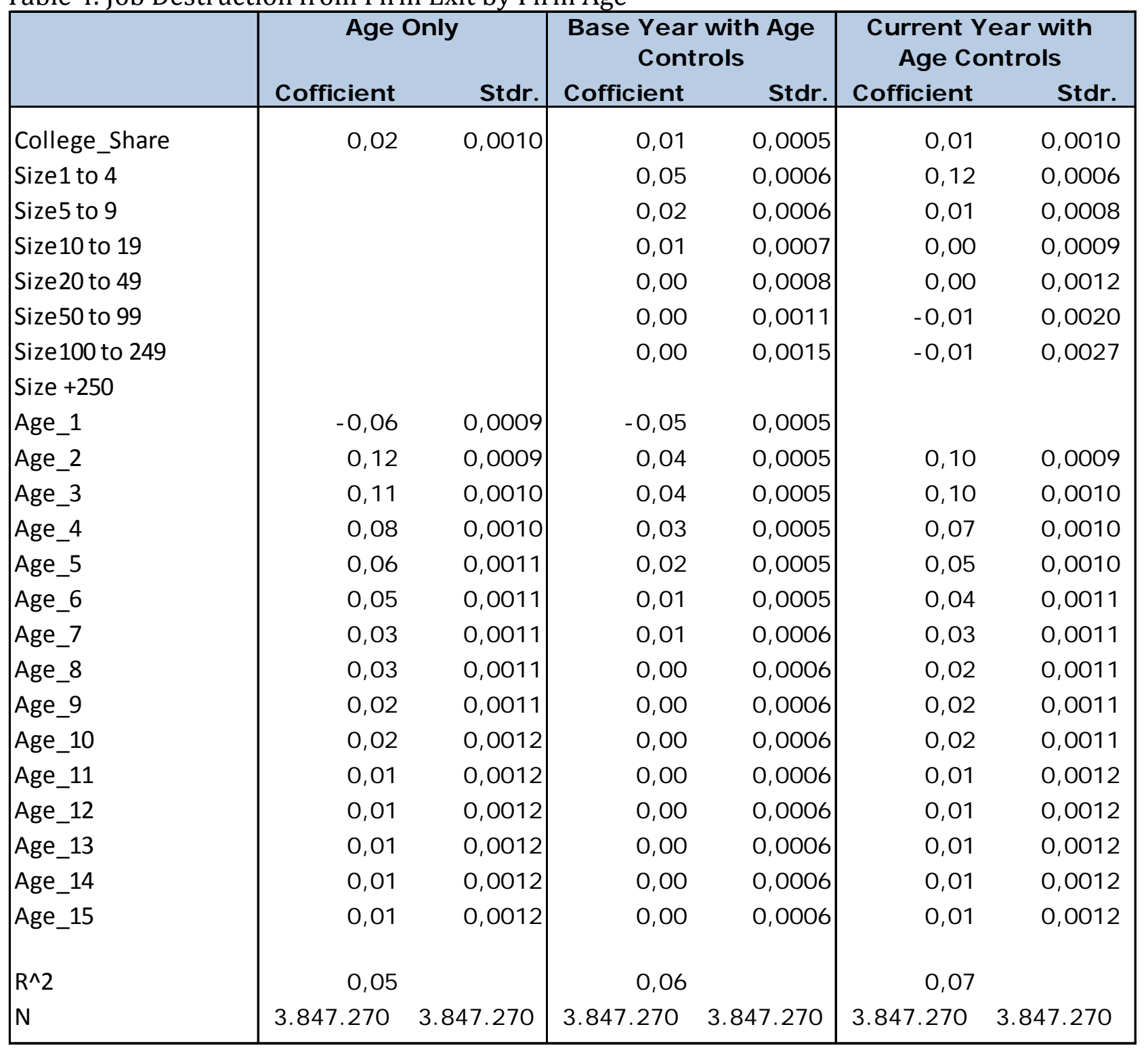


Table 5. Job Creation New and Upsizing Firms without M\&A

\begin{tabular}{|c|c|c|c|c|c|c|c|c|c|c|}
\hline & \multicolumn{2}{|c|}{ Base Year Size } & \multicolumn{2}{|c|}{ Curent (Avg) Size } & \multicolumn{2}{|c|}{ Age Only } & \multicolumn{2}{|c|}{$\begin{array}{l}\text { Base Year with Age } \\
\text { Controls }\end{array}$} & \multicolumn{2}{|c|}{$\begin{array}{c}\text { Current Year with } \\
\text { Age Controls }\end{array}$} \\
\hline & Cofficient & Std.err & Cofficient & Stdr. & Cofficient & Stdr. & Cofficient & Stdr. & Cofficient & Stdr. \\
\hline College_Share & 0,13 & 0,0014 & 0,11 & 0,0015 & 0,15 & 0,0013 & 0,11 & 0,0014 & 0,10 & 0,0013 \\
\hline Size1 to 4 & 0,29 & 0,0016 & 0,38 & 0,0009 & & & 0,21 & 0,0016 & 0,28 & 0,0008 \\
\hline Size5 to 9 & 0,12 & 0,0018 & 0,13 & 0,0011 & & & 0,10 & 0,0017 & 0,16 & 0,0010 \\
\hline Size 10 to 19 & 0,09 & 0,0019 & 0,10 & 0,0014 & & & 0,08 & 0,0019 & 0,14 & 0,0013 \\
\hline Size 20 to 49 & 0,07 & 0,0022 & 0,08 & 0,0017 & & & 0,07 & 0,0021 & 0,13 & 0,0016 \\
\hline Size50 to 99 & 0,06 & 0,0032 & 0,07 & 0,0030 & & & 0,06 & 0,0031 & 0,13 & 0,0027 \\
\hline Size 100 to 249 & 0,05 & 0,0042 & 0,06 & 0,0040 & & & 0,05 & 0,0041 & 0,12 & 0,0037 \\
\hline Size +250 & & & & & & & & & & \\
\hline Age_1 & & & & & 1,22 & 0,0012 & 0,49 & 0,0013 & 1,13 & 0,0012 \\
\hline Age_2 & & & & & 0,37 & 0,0013 & 0,26 & 0,0013 & 0,33 & 0,0012 \\
\hline Age_3 & & & & & 0,18 & 0,0013 & 0,11 & 0,0014 & 0,15 & 0,0013 \\
\hline Age_4 & & & & & 0,15 & 0,0014 & 0,08 & 0,0014 & 0,12 & 0,0014 \\
\hline Age_5 & & & & & 0,13 & 0,0014 & 0,07 & 0,0015 & 0,10 & 0,0014 \\
\hline Age_6 & & & & & 0,12 & 0,0014 & 0,06 & 0,0015 & 0,09 & 0,0014 \\
\hline Age_7 & & & & & 0,11 & 0,0015 & 0,05 & 0,0015 & 0,09 & 0,0015 \\
\hline Age_8 & & & & & 0,09 & 0,0015 & 0,04 & 0,0016 & 0,07 & 0,0015 \\
\hline Age_9 & & & & & 0,09 & 0,0015 & 0,04 & 0,0016 & 0,07 & 0,0015 \\
\hline Age_10 & & & & & 0,08 & 0,0016 & 0,04 & 0,0016 & 0,06 & 0,0015 \\
\hline Age_11 & & & & & 0,07 & 0,0016 & 0,03 & 0,0016 & 0,05 & 0,0016 \\
\hline Age_12 & & & & & 0,07 & 0,0016 & 0,03 & 0,0017 & 0,05 & 0,0016 \\
\hline Age_13 & & & & & 0,06 & 0,0016 & 0,03 & 0,0017 & 0,04 & 0,0016 \\
\hline Age_14 & & & & & 0,05 & 0,0016 & 0,02 & 0,0017 & 0,04 & 0,0016 \\
\hline Age_15 & & & & & 0,05 & 0,0017 & 0,02 & 0,0017 & 0,03 & 0,0017 \\
\hline$R^{\wedge} 2$ & 0,16 & & 0,23 & & 0,35 & & 0,19 & & 0,38 & \\
\hline $\mathrm{N}$ & 3.847 .279 & 3.847 .279 & 3.847 .279 & 3.847 .279 & 3.847 .279 & 3.847 .279 & 3.847.279 & 3.847 .279 & 3.847 .279 & 3.847 .279 \\
\hline
\end{tabular}


Table 6. Job Destruction Closed and Downsizing Firms without M\&A

\begin{tabular}{|c|c|c|c|c|c|c|c|c|c|c|}
\hline & \multicolumn{2}{|c|}{ Base Year Size } & \multicolumn{2}{|c|}{ Curent (Avg) Size } & \multicolumn{2}{|c|}{ Age Only } & \multicolumn{2}{|c|}{ Base Year with Age } & \multicolumn{2}{|c|}{ Current Year with } \\
\hline & Cofficient & Std.err & Cofficient & Stdr. & Cofficient & Stdr. & Cofficient & Stdr. & Cofficient & Stdr. \\
\hline College_Share & $-0,04$ & 0,0007 & $-0,14$ & 0,0014 & $-0,09$ & 0,0014 & $-0,04$ & 0,0007 & $-0,15$ & 0,0014 \\
\hline Size1 to 4 & 0,14 & 0,0009 & 0,34 & 0,0008 & & & 0,14 & 0,0009 & 0,37 & 0,0008 \\
\hline Size 5 to 9 & 0,12 & 0,0009 & 0,14 & 0,0011 & & & 0,12 & 0,0009 & 0,15 & 0,0011 \\
\hline Size 10 to 19 & 0,10 & 0,0010 & 0,10 & 0,0013 & & & 0,09 & 0,0010 & 0,12 & 0,0013 \\
\hline Size 20 to 49 & 0,08 & 0,0011 & 0,08 & 0,0016 & & & 0,08 & 0,0011 & 0,10 & 0,0016 \\
\hline Size50 to 99 & 0,07 & 0,0017 & 0,07 & 0,0028 & & & 0,07 & 0,0017 & 0,09 & 0,0028 \\
\hline Size 100 to 249 & 0,06 & 0,0022 & 0,07 & 0,0039 & & & 0,06 & 0,0022 & 0,09 & 0,0038 \\
\hline Size +250 & & & & & & & & & & \\
\hline Age_1 & & & & & $-0,20$ & 0,0013 & $-0,15$ & 0,0007 & $-0,35$ & 0,0013 \\
\hline Age_2 & & & & & 0,17 & 0,0013 & 0,05 & 0,0007 & 0,10 & 0,0013 \\
\hline Age 3 & & & & & 0,18 & 0,0014 & 0,06 & 0,0007 & 0,12 & 0,0014 \\
\hline Age_4 & & & & & 0,14 & 0,0015 & 0,04 & 0,0008 & 0,09 & 0,0014 \\
\hline Age 5 & & & & & 0,11 & 0,0015 & 0,03 & 0,0008 & 0,06 & 0,0015 \\
\hline Age_6 6 & & & & & 0,10 & 0,0015 & 0,03 & 0,0008 & 0,05 & 0,0015 \\
\hline Age 7 & & & & & 0,08 & 0,0016 & 0,02 & 0,0008 & 0,04 & 0,0015 \\
\hline Age_8 & & & & & 0,07 & 0,0016 & 0,01 & 0,0008 & 0,03 & 0,0016 \\
\hline Age_9 & & & & & 0,06 & 0,0016 & 0,01 & 0,0009 & 0,02 & 0,0016 \\
\hline Age_10 & & & & & 0,04 & 0,0017 & 0,01 & 0,0009 & 0,01 & 0,0016 \\
\hline Age_11 & & & & & 0,04 & 0,0017 & 0,00 & 0,0009 & 0,01 & 0,0016 \\
\hline Age_12 & & & & & 0,04 & 0,0017 & 0,00 & 0,0009 & 0,01 & 0,0016 \\
\hline Age_13 & & & & & 0,03 & 0,0017 & 0,00 & 0,0009 & 0,00 & 0,0017 \\
\hline Age_14 & & & & & 0,03 & 0,0018 & 0,00 & 0,0009 & 0,00 & 0,0017 \\
\hline Age_15 & & & & & 0,03 & 0,0018 & 0,00 & 0,0009 & 0,00 & 0,0017 \\
\hline$R^{\wedge} 2$ & 0,19 & & 0,20 & & 0,17 & & 0,20 & & 0,22 & \\
\hline $\mathrm{N}$ & 3.847 .279 & 3.847 .279 & 3.847 .279 & 3.847 .279 & 3.847 .279 & 3.847 .279 & 3.847 .279 & 3.847 .279 & 3.847 .279 & 3.847 .279 \\
\hline
\end{tabular}




\section{Appendix A.}

\section{Growth rate, job creation and job destruction.}

The growth rate for firm $i$ at time $t$ is given by

$g_{\text {it }}=\left(E_{i t}-E_{\text {it }-1}\right) / X_{i v}$

where $\mathrm{E}$ is number of employees at time $\mathrm{t}$ and $\mathrm{t}-1$ and $\mathrm{X}$ is given by

$X_{i t}=0.5 *\left(E_{i t}+E_{t-1}\right)$

the current size, that is the average size from time $t-1$ to time $t$.

Job creation and job destruction for firm $i$ at time $t$ is given by

$J C_{\text {it }}=\max \left(g_{i t}, 0\right)$

$J D_{i f}=\max \left(-g_{i t}, 0\right)$

and firm entry is given by

$J C_{\text {it }}=\max \left(g_{i t}, 0\right) * I\left\{g_{\text {it }}=2\right\}$

where I is one, when the expression in the brackets hold and zero if not. $g_{i t}=2$ denotes an entrant.

Firm exit is given by

$J D_{\text {if }}=\max \left(-g_{\text {if }}, 0\right) * I\left\{-g_{\text {it }}=2\right\}$

where I means the same as for entrants and $g_{i t}=-2$ denotes an exit. 